\title{
1 Evidence and causes of the main extinction events in the Paleogene based on extinction and survival patterns of foraminifera
}

\author{
Q14 Eustoquio Molina*
}

Departamento de Ciencias de la Tierra and IUCA, Universidad de Zaragoza, Pedro Cerbuna, 12, E-50009 Zaragoza, Spain

\section{A R T I C L E I N F O}

\section{Article history:}

Received 17 July 2014

Accepted 14 November 2014

Available online $\mathrm{xxxx}$

\section{Keywords:}

Extinction

Survival strategy

Planktic foraminifera

Benthic foraminifera

Paleogene

\begin{abstract}
A B S T R A C T
We review the four main extinction events in the Paleogene, from the Cretaceous/Paleogene boundary to the 16 Eocene/Oligocene boundary, integrating the results obtained from a study of foraminiferal assemblages with 17 other paleontological and geological data. Different survival strategies followed by the species are described 18 and the duration of the phases of extinction, survival, and recovery is estimated. The models and patterns of 19 extinction of the foraminifera are highlighted. We present a range of evidence and paleo-environmental factors 20 and analyze the possible causes of extinction. A new terminology for mass extinction events is proposed: sudden 21 mass extinction would have happened virtually instantaneously and the process would have taken a few years or 22 decades (Cretaceous/Paleogene boundary). Rapid mass extinction is defined as that which occurred in relatively 23 short events, around 100 kyr (Paleocene/Eocene and Eocene/Oligocene boundaries). Slow mass extinctions are 24 suggested to have lasted around $1 \mathrm{Myr}$ (Bartonian/Priabonian transition) and may even have lasted for several 25 million years.
\end{abstract}

\section{Contents}

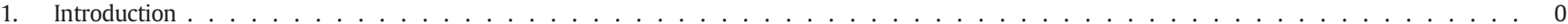

2. Materials and methods . . . . . . . . . . . . . . . . . . . . . . . . . . . . . . . . . . . . . . . . . . . . . . . . 0

3. The Cretaceous/Paleogene boundary event . . . . . . . . . . . . . . . . . . . . . . . . . . . . . . . . . . . . . . . 0

4. The Paleocene/Eocene boundary event . . . . . . . . . . . . . . . . . . . . . . . . . . . . . . . . . . . . . . . . . . . . . . 0

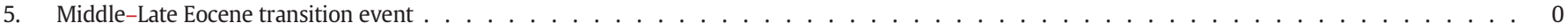

6. Eocene/Oligocene extinction event . . . . . . . . . . . . . . . . . . . . . . . . . . . . . . . . . . . . . . . . . 0

7. Discussion and conclusions ... . . . . . . . . . . . . . . . . . . . . . . . . . . . . . . . . . 0

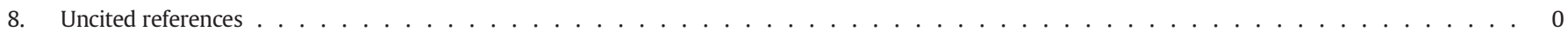

Acknowledgments. . . . . . . . . . . . . . . . . . . . . . . . . . . . . . . . . . . . . . . . . . . . . . . . . 0

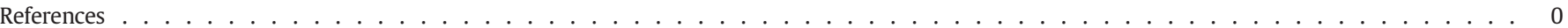

\section{Introduction}

The first general insights into the extinction events of organisms were those of some naturalists in the 18th and early 19 th centuries, such as Georges Louis Leclerc (Buffon) and Georges Cuvier, who drew attention to the extinction of species in the fossil record, which gave rise to the catastrophist paradigm (Rudwick, 2008). In the 19th century, the French naturalist Alcide d'Orbigny, founder of the field of Micropaleontology, proposed the existence of 27 total extinctions followed by as many successive periods of creation (Moreau and Dory, 2005).

\footnotetext{
* Tel.: + 34976 761077; fax: + 34976761106.

E-mail address: emolina@unizar.es.
}

The catastrophist paradigm was soon replaced by the uniformitarian 54 paradigm, which also accepted the concept of extinction. Darwin 55 (1859) suggested the successive gradual extinction of species, one 56 after another, and claimed that natural selection could adequately ex- 57 plain it. He attributed massive extinction events to imperfections in 58 the fossil record. From the 19th century until relatively recently, there 59 have been several authors who dealt with the subject such as the 60 German Schindewolf (1963), but the question of extinction events 61 had not aroused great interest until Alvarez et al. (1980) proposed the 62 impact theory. This theory has revolutionized the field of Earth Sciences, 63 contributing to the replacement of the gradual evolutionary paradigm 64 by the neo-catastrophist evolutionary paradigm. In the past three 65 decades, a large amount of data has been gathered on the various 66 extinction events and theoretical concepts have been developed for 67 
the phenomenon of extinction (Berggren and Van Couvering, 1984; Chaloner and Hallam, 1989; Donovan, 1989; Kauffman and Walliser, 1990; Raup, 1991; Glen, 1994; Molina, 1994; Hart, 1996; Hallam and Vignall, 1997; Palmer, 2003; Molina, 2004; Taylor, 2004; Twitchett, 2006, among others).

In addition to the background extinction process, which makes species disappear slowly and continually due mainly to biological causes (e.g. competition, endemism), there were periods of time in which the rate of extinction accelerated, giving rise to mass extinction events. There are basically two models: gradual mass extinction and catastrophic mass extinction, the latter of which should be more correctly termed 'sudden' as opposed to 'gradual' (Molina, 1995, 2006, 2007). Gradual mass extinctions can be subdivided according to their duration. Mass extinction events are mainly triggered by geological or extraterrestrial causes (Alvarez et al., 1980; Kaiho, 1994; Thomas, 2007; Schulte et al., 2010; McGowran, 2012, among others). Biological causes, such as the predominance of a single species, do not appear to have been the origin of mass extinctions, during the greater part of the Phanerozoic. However, recent data suggest that an event of this type is currently on-going: the most obvious cause of the mass extinction event is the extraordinary proliferation of the human species and its industrial activities (Leakey and Lewin, 1995).

Paleontologists have demonstrated that mass extinctions are selective and have affected some species more than others. During a mass extinction event, three phases or intervals can be identified: extinction, survival, and recovery (Kauffman and Erwin, 1995; Kauffman and Harries, 1996). In the course of these phases the different taxa react in a variety of ways, becoming extinct at the moment of the event (extinct taxa) or shortly thereafter (delayed extinction taxa), taking advantage opportunistically of the altered conditions (disaster taxa), fleeing from the altered conditions by migrating to refuges from which they return when conditions return to normal (Lazarus taxa), generating new more or less ephemeral forms that represent the beginning of new lineages (progenitor taxa), or resisting the altered environmental conditions (survivor taxa). Apart from the background extinctions, that result from normal competition and natural selection, it is generally accepted that throughout the Phanerozoic there have been five major mass extinction events, which occurred at the end of the Ordovician, the Frasnian (Late Devonian), the Permian, the Triassic, and the Cretaceous (Hallam and Vignall, 1997). Furthermore, there were many other significant mass extinction events, although of smaller amplitude than the five major extinctions, and several of them were in the Paleogene.

After the mass extinction at the Cretaceous/Paleogene boundary, organisms started new evolutionary trends as a greenhouse world evolved into an icehouse world, including rapid global warming and cooling events during the Paleogene. Foraminiferal extinctions are mainly related to meteorite impacts, hyperthermal events, glaciation events and other geologic phenomena. The chronology of the Paleogene Period has recently been updated (Wade et al., 2011; Vandenberghe et al., 2012), allowing a more accurate evaluation of the patterns and duration of the Paleogene extinction events. The aim of this review paper is to analyze the extinction events of the Cretaceous/Paleogene, Paleocene/Eocene, Middle-Late Eocene and Eocene/Oligocene, evaluating the magnitude of each event, its causes, extinction patterns, and survival strategies of planktic and smaller benthic foraminifera. In addition, we propose a new terminology for mass extinction events and we estimate the duration of the principal extinction events of the Paleogene.

\section{Materials and methods}

Not all groups of fossilized organisms allow us to ascertain with the same degree of precision their extinction patterns and survival strategies, since they require highly detailed biostratigraphic studies which for many groups are just not possible. A good number of groups were highly restricted to particular environments or were very rarely fossil- 132 ized, making it difficult to establish their models and causes of extinc- 133 tion. The best example of this is the dinosaur fossil record, which 134 is often so patchy that it will probably take a long time to determine de- 135 finitively whether they became extinct in a gradual or sudden manner, 136 as their study is strongly influenced by what is known as the "Signor- 137 Lipps effect" (Signor and Lipps, 1982). The foraminifera, on the other 138 hand, due to their small sizes, wide distribution and abundance in 139 ocean environments, are enormously useful and allow us to study 140 their ecological patterns and strategies in detail, based on which we 141 can then deduce the causes of extinction, especially in the Paleogene 142 (Molina, 1995, 2006). In order to facilitate comparison among different 143 sections and make world-wide correlations, foraminiferal taxonomy 144 has been revised and updated according to Olsson et al. (1999) and 145 Pearson et al. (2006). Furthermore, standard chrono-biostratigraphy 146 has been updated (Fig. 1) and range charts (Figs. 2 to 6) have been sim- 147 plified to better show the patterns of extinction.

The outcrop sections and boreholes (DSDP and ODP sites) studied, 149 on which this paper is based, cover a wide range of locations around 150 the world, mainly in intermediate and low latitudes. In Spain, they in- 151 clude the Betics (Agost, Alamedilla, Aspe, Caravaca, El Navazuelo, Fuente 152 Caldera, Molino de Cobo, and Torre Cardela) and the Pyrenees (Arguis, 153 Artieda, Campo, Osinaga, and Zumaya). In Italy: Gubbio, Massignano 154 and Possagno. In France: Bidart and the Bay of Loye. In Tunisia: El Kef, 155 Aïn Settara and Elles. In Egypt: Dababiya. In Mexico: Coxquihui, El 156 Mimbral, La Lajilla, and La Ceiba. In Cuba: Loma Capiro, Peñalver 157 and Santa Isabel. In the Atlantic Ocean: DSDP sites 94, 116, 363, 158 366, 401, 402, and 612. In the Indian Ocean: DSDP sites 214, 216, 219, 159 223, 242, and 253. In the Pacific Ocean: DSDP sites 277, 292, and 462160 (see Molina et al., 1993, 1998, 2009).

Detailed samplings were conducted on a metric scale, but where 162 extinction or meteorite impact events were located, sampling density 163 was from 2 to $20 \mathrm{~cm}$. At the levels closest to the event, continuous sam- 164 ples were taken with a resolution of $2 \mathrm{~cm}$. The samples were disaggre- 165 gated with water and washed, and the fractions greater than $150 \mu \mathrm{m}, 166$ $100 \mu \mathrm{m}$ or $63 \mu \mathrm{m}$ were studied according to the size of the foraminifera 167 in each section and event. In many sections, quantitative studies were 168 conducted, separating a representative fraction of more than 300 spec- 169 imens in each sample, using an Otto microsplitter and also checking the 170 rest of the sample for less frequent species.

\section{The Cretaceous/Paleogene boundary event}

The Cretaceous/Paleogene boundary event $(\mathrm{K} / \mathrm{Pg})$ is one of the most 173 widely studied as it is the most recent of the 5 major mass extinctions, it 174 has been dated to 66.04 Ma (Vandenberghe et al., 2012). The stratotype 175 for the $\mathrm{K} / \mathrm{Pg}$ boundary was defined at the base of the clay that contains 176 the iridium anomaly in the El Kef section in Tunisia (Molina et al., 2006a, 177 2009). This event, which constitutes one of the most significant biolog- 178 ical crises in geological history, is used to define the boundary between 179 the Mesozoic and Cenozoic Eras.

Alvarez et al. (1980) proposed that the collision of a large meteorite 181 measuring some $10 \mathrm{~km}$ in diameter may have produced a level abnor- 182 mally rich in iridium that coincided with the sudden catastrophic 183 mass extinction. This evidence was recorded in a thin clay interval 184 at the K/Pg boundary in Gubbio (Italy), Stevns Klint (Denmark) and 185 Woodside Creek (New Zealand), as well as in Caravaca (Spain) (Smit 186 and Hertogen, 1980). In addition, other evidence at the K/Pg boundary 187 has been found, such as microtektites, Ni-rich spinels, shocked quartz, 188 which, combined with the discovery of a large impact crater structure 189 in the Yucatan peninsula, the sedimentological evidence of tsunamis 190 and gigantic gravitational flows as well as the dating by ${ }^{40} \mathrm{Ar} /{ }^{39} \mathrm{Ar}$ of 191 the impact silica glass have enabled to confirm the validity of the impact 192 theory (Schulte et al., 2010).

However, since the classic sections of Gubbio and Caravaca are com- 194 posed of rocks that were formed in deep ocean settings, they do not 195 


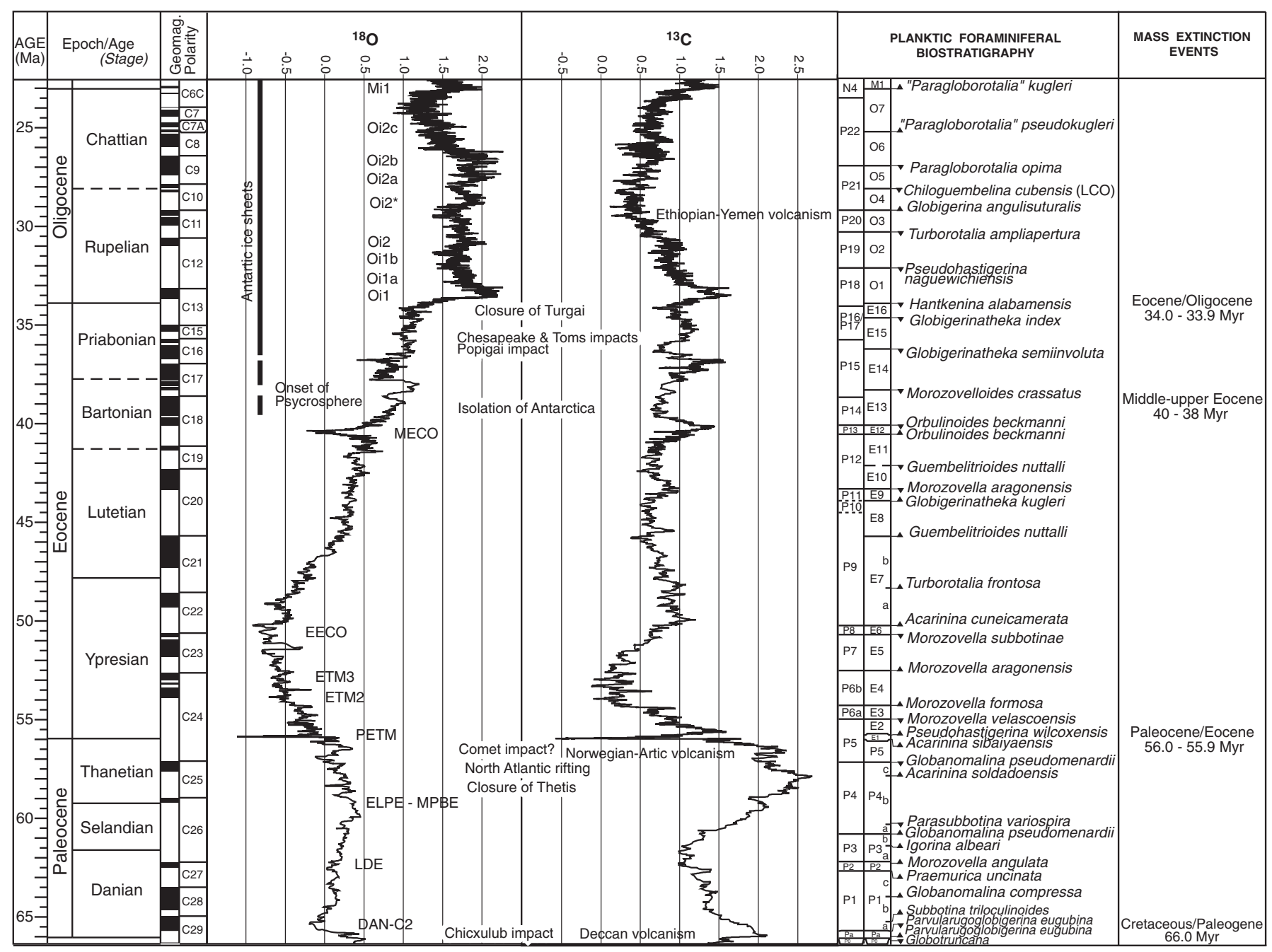

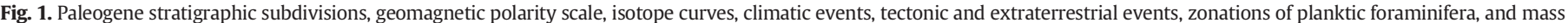
extinction events.

Modified and completed from Vandenberghe et al. in The Geologic Time Scale (Gradstein et al., 2012).

contain remains of dinosaurs and only scant fossils of other groups: ammonites, belemnites and rudist bivalves, which also went extinct. Hence, it is the planktic foraminifera that, thanks to their abundance and small size, are allowing us to show that the impact level and mass extinction were contemporaneous (e.g., Molina, 2006, 2007).

The methodology used in the study of planktic foraminifera, both in the field (high-resolution sampling) and in the laboratory (extraction and observation techniques, quantitative studies), allows us to determine with great precision the pattern of extinction and ascertain its most probable cause. Initially, before the impact theory was put forward, the extinction pattern of the planktic foraminifera at the $\mathrm{K} / \mathrm{Pg}$ event seemed to be almost total (Luterbacher and Premoli Silva, 1964). Subsequently, when high-resolution studies began, the pattern appeared to be gradual; some thought it was fairly gradual (Lamolda et al., 1983; Canudo et al., 1991) while for others it was very gradual (Keller, 1988). Currently, after a long controversy, most specialists agree that we are dealing with a sudden pattern (Smit, 1982, 1990; Molina et al., 1996, 1998, 2005; Apellaniz et al., 1997; Orue-Etxebarria, 1997; Arz et al., 1999, 2000, 2001; Kaiho and Lamolda, 1999; Arenillas et al., 2000a, 2000b, 2006; Dupuis et al., 2001; MacLeod et al., 2007). However, there are authors who maintain that the extinction pattern is one of gradual mass extinction (e.g., Keller et al., 1995; Keller, 2012).

The best sections at the K/Pg boundary for the study of the planktic foraminifera extinction pattern are found in Tunisia (El Kef, Aïn Settara,
Elles), France (Bidart) and Spain (Agost, Caravaca, Zumaya), while the 220 best ones for studying the evidence of the meteorite impact are in the 221 coastal area of the Gulf of Mexico and the Caribbean, specifically in 222 Mexico (Coxquihui, El Mimbral, La Lajilla, and La Ceiba) and in Cuba 223 (Loma Capiro, Peñalver, and Santa Isabel). Of all of these it is the El Kef 224 section that stands out as the most reliable source of data thanks to its 225 considerable continuity and great wealth of planktic foraminifera, as 226 well as being the location that we have studied most intensely (Fig. $2 ; 227$ Arenillas et al., 2000a; Molina et al., 2006a, 2009). We found that the 228 planktic foraminifera display a sudden catastrophic mass extinction 229 pattern that affected more than $70 \%$ of the species, which became 230 extinct suddenly coinciding with the level containing the evidence of 231 the meteorite impact. The presence in the Danian of specimens of 232 some Cretaceous species may be due to allochronic resedimentation, 233 since they were the smallest and most abundant species in the upper- 234 most Cretaceous and, therefore, the most likely to be reworked; more- 235 over, they are not found throughout the Danian in all continuous 236 sections of the K-Pg transition and they tend to be less well preserved 237 and different in color. If we discount these species, whose survival is 238 very doubtful, the mass extinction would have affected about $90 \%$ of 239 all planktic foraminifera, exactly as we have also observed in Bidart 240 (Gallala et al., 2009).

The species that disappeared in environments of sub-tropical lati- 242 tudes like El Kef amount to $91 \%$ of the species, which became extinct 243 


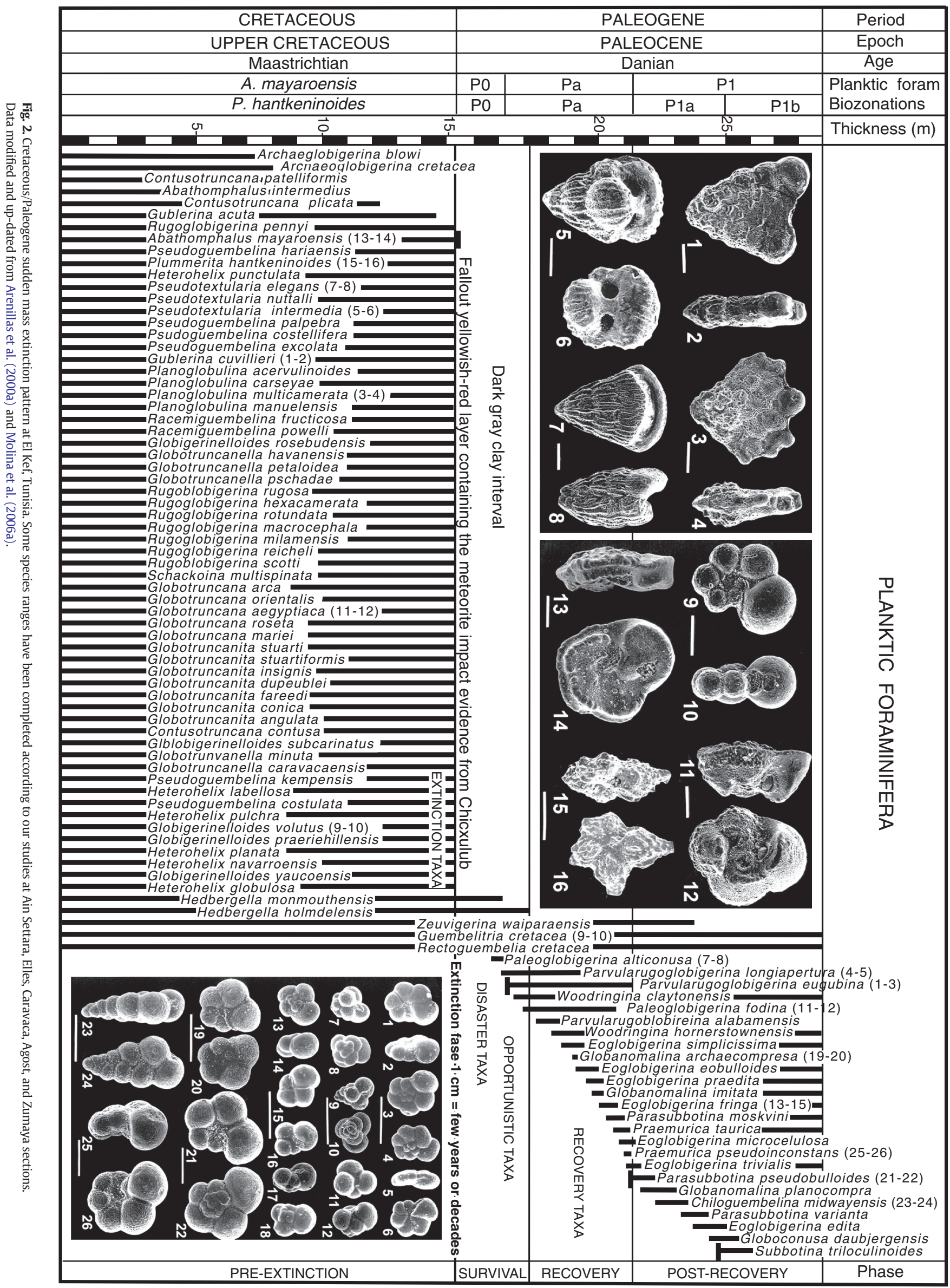




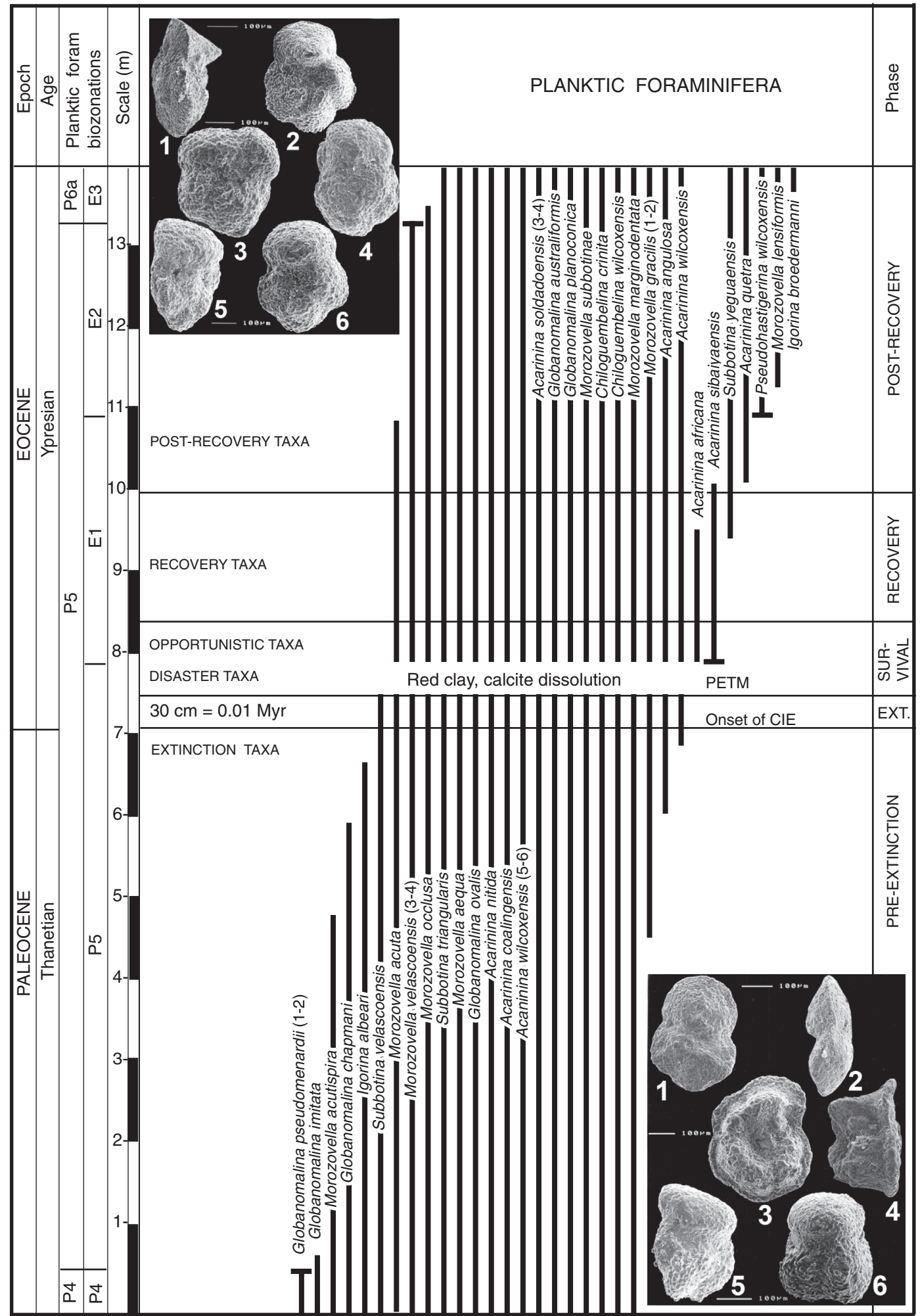

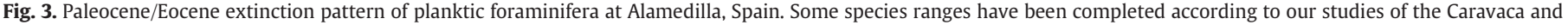
Zumaya sections.

Data modified and updated from Arenillas and Molina (1996) and Molina et al. (1999).

suddenly. Most of them had large tests and complex morphologies, and were specialized forms of K-selection strategy, that had adapted to deep-water environments in warm latitudes such as: Globotruncana arca or Abathomphalus mayaroensis. Therefore, this event is the most relevant and counts as the greatest morphological renewal in the entire history of the planktic foraminifera, with the total disappearance of all 249 forms with two keels and tegilla.

The total number fell by much larger percentages, to such an extent 251 that in the boundary clay it is hard to find enough specimens to carry 252 out quantitative analysis. Very few species of planktic foraminifera 253 


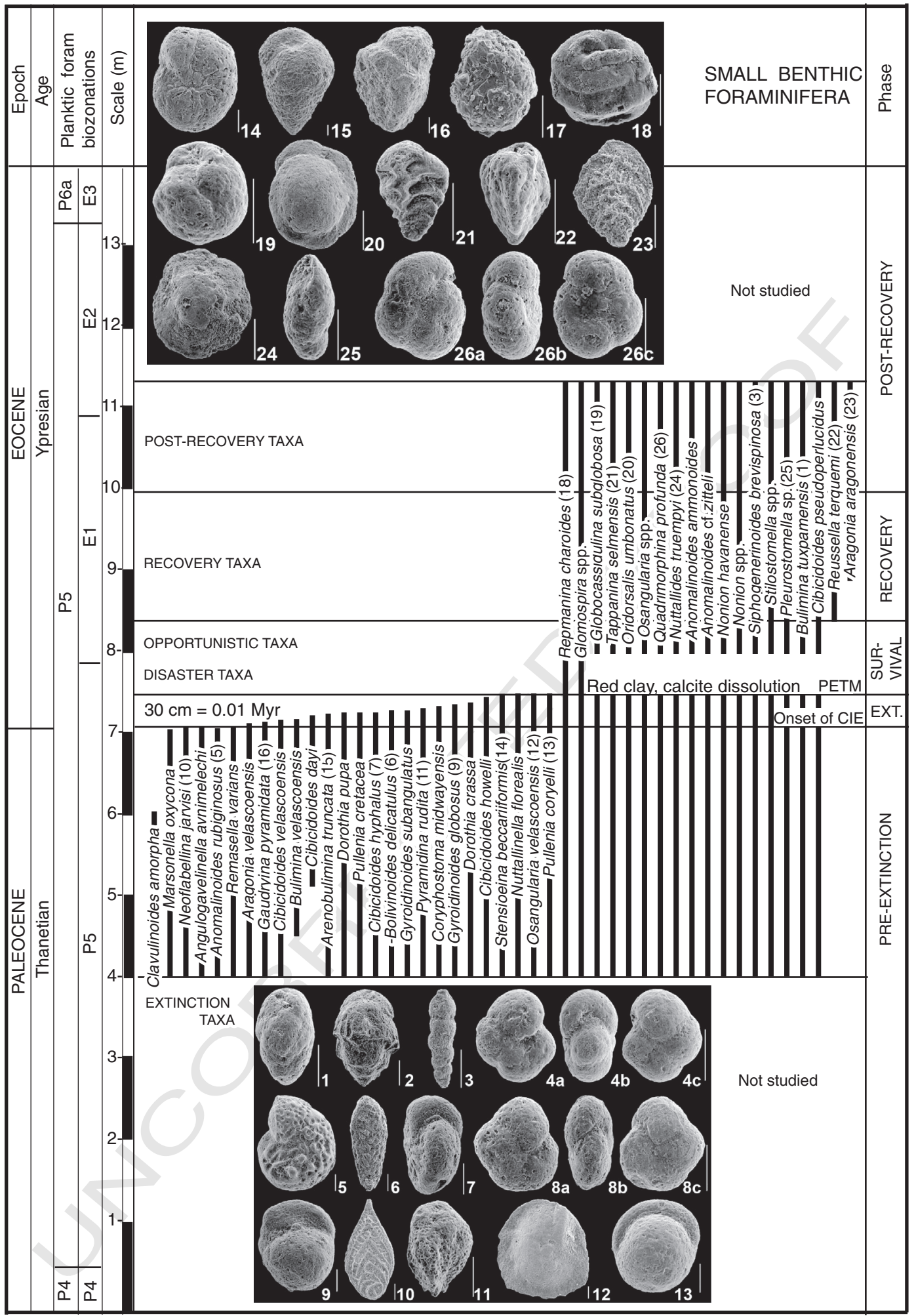

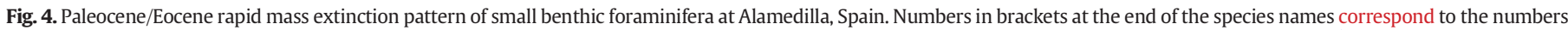
in microphotographs.

Data modified and updated from Alegret et al. (2009).

survived the $\mathrm{K} / \mathrm{Pg}$ boundary event, just three delayed extinction species and two disaster species did so. The delayed extinction species Hedbergella monmouthensis and Hedbergella holmdelensis, were small in size, survived initially and became extinct shortly after the event. The disaster species Guembelitria cretacea and Rectoguembelina cretacea, flourished in the survival phase thanks to their r-selection strategy. 259 The progenitor species that appeared at the base of the Paleogene 260 are: Paleoglobigerina alticonusa, Parvularugoglobigerina longiapertura, 261 Parvularugoglobigerina eugubina, Woodrigina claytonensis, and 262 Paleoglobigerina fodina. These species are widely distributed, since 263 


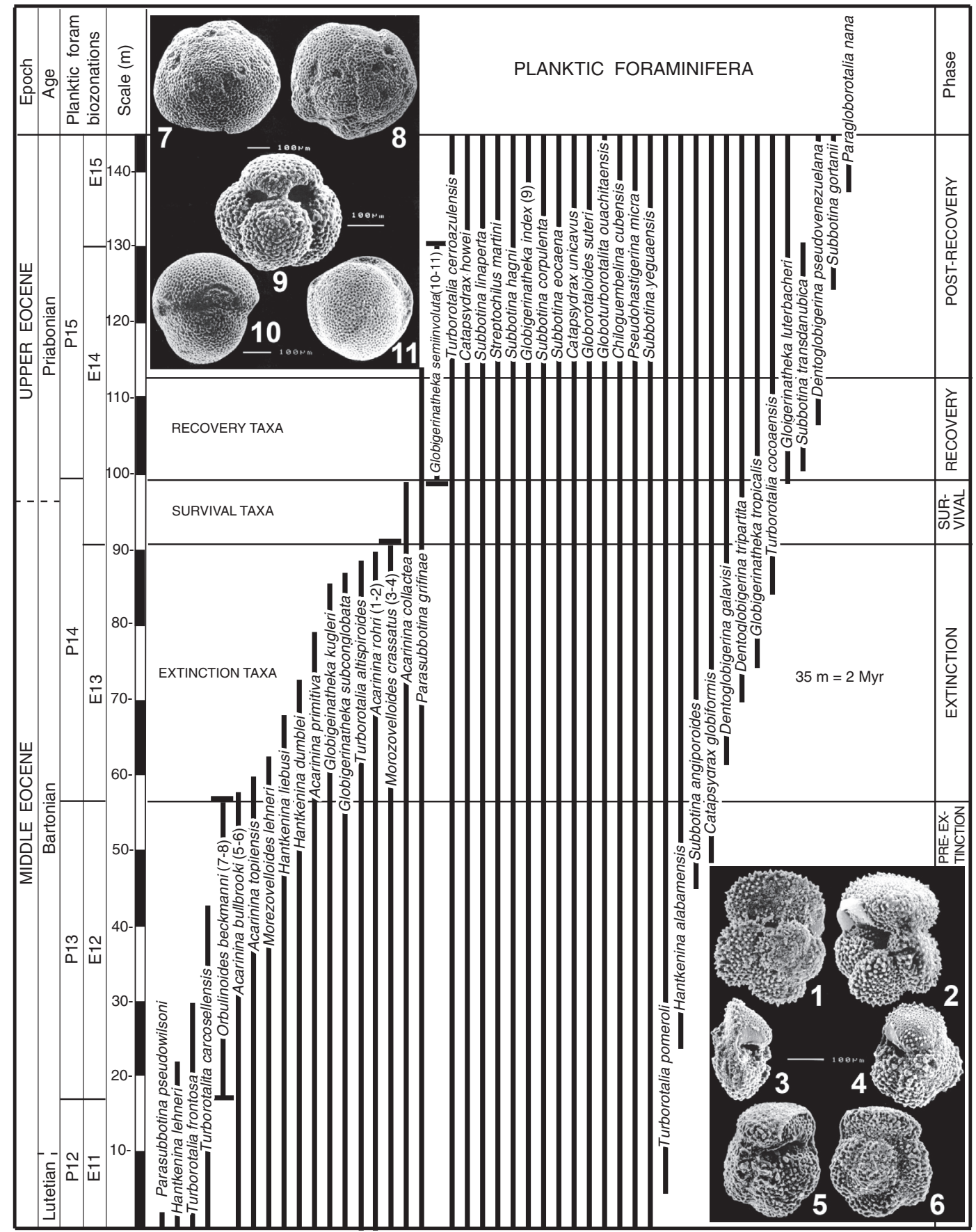

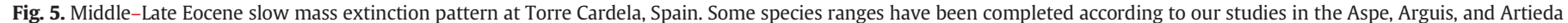
sections.

Q1 Data modified and updated from Gonzalvo and Molina (1996).

almost all of them can be found in the majority of sections studied. They went extinct at the end of the recovery phase, with the exception of $W$. claytonensis.

There appear to be no Lazarus taxa among the planktic foraminifera, as the extinction was so massive that few species were left that could develop this strategy. However, it is very frequent among the small benthic foraminifera that lived in deep-ocean environments (Coccioni and Galeotti, 1994; Alegret et al., 2002; Peryt et al., 2002; Alegret et al., 2003, 2004a, 2004b). This group was less affected by the K/Pg event as its diet did not depend directly on photosynthesis since it inhabited the aphotic zone, and since before the mass extinction there was equilibrium between of infaunals and epifaunals. In Tunisia, in the El Kef section, the sudden disappearance of 13 species of benthic foraminifera 276 can be observed, of which the following can be considered extinct: 277 Cibicides beaumontianus, Heterostomella austiniana, Bolivinoides draco, 278 Praebulimina kickapooensis, Sitella cushmani, and Sitella fabilis (Molina 279 et al., 2006a). Following the extinction event the conditions were 280 oligotrophic; many species behaved like Lazarus taxa and reappeared 281 during the recovery phase. In the Gulf of Mexico and the Atlantic 282 sections, however, this is not the case. There, the Lazarus species 283 tend to be epifaunal, such as Cibicidoides dayi and Nuttallides florealis. 284 However, in the Tethys there are quite a few infaunals that behaved 285 as Lazarus species: Arenobulimina truncata, Bolivinoides delicatulus, 286 Gaudryina pyramidata, Oridorsalis umbonatus, and Praebulimina reussi 287 


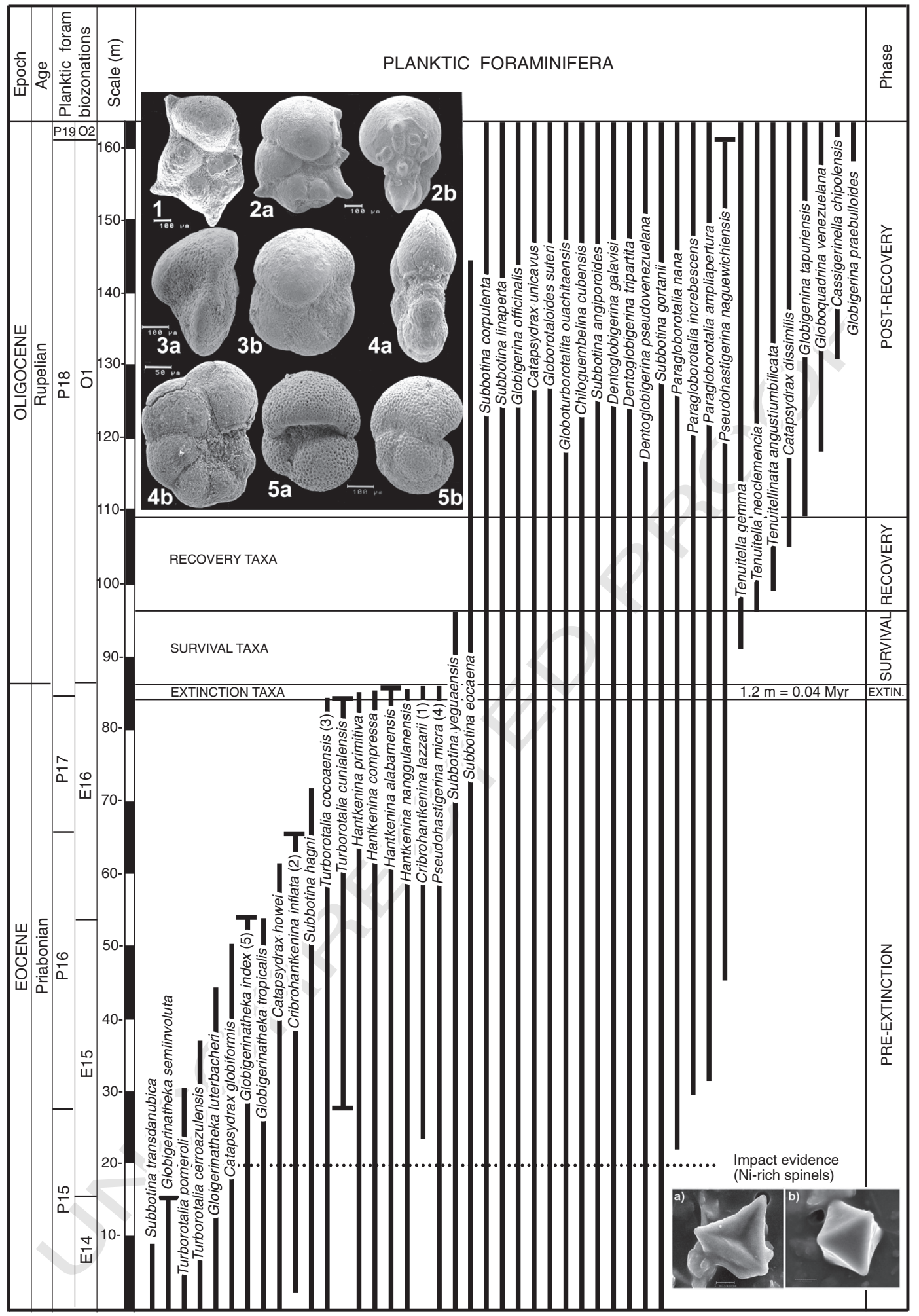

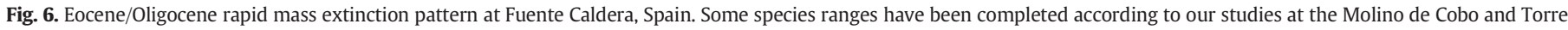
Cardela sections.

Data modified and updated from Molina (1986), Robin and Molina (2006), and Molina et al. (2006b).

(Peryt et al., 2002; Alegret et al., 2003). However, it has to be considered that carbonate dissolution affects the record of these species in the clay at the K/Pg boundary in deep ocean sections. In the Bidart section of the Bay of Biscay, various species, mainly epifaunal, proliferated after the extinction event: Coryphostoma incrasata (in the gigantea form),
Stensioeina beccariiformis, Cibicidoides hyphalus, and Angulogavelinella 293 avnimelechi, which may be regarded as opportunistic species that took 294 advantage of the crisis (Alegret et al., 2004a). However, S. beccariiformis 295 and $A$. avnimelechi are generally regarded as indicators of stable oligotro- 296 phic deep-water settings, which can support highly diverse ecosystems 297 
(Thomas, 2007). In the El Kef section in Tunisia, the opportunistic species that most proliferated was Cibicidoides pseudoacutus. Once environmental conditions began to recover, a gradual increase in epifaunal species, mainly of the genera Anomalinoides and Nuttallides replaced the opportunists. According to Alegret et al. (2012), the end-Cretaceous marine mass extinction was not caused by a collapse in productivity in the deep sea.

The extinction pattern of the planktic foraminifera indicates a sudden mass extinction, as $91 \%$ of the species disappeared almost instantaneously in terms of geological time. The extinction phase, which was extremely short, is in the order of years or decades, and a rapid shortterm cooling followed the Chicxulub impact (Vellekoop et al., 2014). In sections located far from the impact region the sediment is just about one centimeter thick, concentrates at the yellowish-red fallout layer and the interval is so short that cannot be represented in Fig. 2 . The survival phase is clearly demarcated and covers the interval of dark clay of the G. cretacea (P0) biozone, which has been studied with high-resolution bio-magnetostratigraphic calibrations (Arenillas et al., 2004). The recovery phase was longer, as the planktic foraminifera did not regain their normal size until the lower part of the Parasubbotina pseudobulloides (P1) biozone and the density of accumulated sediments is much greater, producing a great diversification in the assemblages of planktic foraminifera, though never reaching the degree of diversity that existed before the extinction event.

The cause that triggered the extinction event was very probably the impact of a large meteorite in the Yucatán Peninsula, where today there is a buried crater (Chicxulub) with a diameter of some $170 \mathrm{~km}$ (Alvarez, 1997; Schulte et al., 2010). In the studied sections, evidence of the impact is evident (the iridium anomaly, microtektites, Ni-rich spinels, shocked quartz with impact metamorphosis) which are concentrated in a single level in the sections in areas far from the Gulf of Mexico. Since this level coincides exactly with the mass extinction, the causeeffect relationship can be established and it is the most plausible explanation. The environments most affected were terrestrial and pelagic marine environments, the catastrophe being so sudden that there was not enough time for natural selection to operate. The carbon and oxygen isotopes indicate a significant reduction in organic productivity and in water temperature. The vaporization of the meteorite and the impacted material, together with the ash from forest fires produced a global atmospheric darkening that lasted several months, which halted photosynthesis and a massive fall in temperature (the "impact winter"). The paleo-botanic record seems to show few extinctions, but sweeping paleo-environmental changes including deforestation and a brutal temporary reduction in diversity (Lazarus effect), with a few opportunistic disaster species (mainly ferns) dominating during the survival stage (Orth et al., 1981). Moreover, there is evidence of acid rain and anoxia or hypoxia in the ocean depths, acidification being the more important factor in the calcareous plankton extinctions (Ohno et al., 2014). The impact produced enormous tsunamis in the area of the Gulf of Mexico, destabilization and rupture of the marine shelf, generating a mega-turbidite mass flow, which in some Cuban sections become an enormous olistostrome reaching dimensions of hundreds of meters (Alegret et al., 2005a).

These sudden paleoenvironmental changes explain the great magnitude of the mass extinction. The catastrophic mass extinction of planktic foraminifera may possibly be extrapolated to the other groups involved in this extinction whose fossil record is not as good. Some authors have attributed this extinction event to intense volcanic activity in the Deccan (India). However, it has been shown by Venkatesan et al. (1993) that this volcanic activity began earlier, spans the K/Pg boundary, and that the injection of sulfur into the atmosphere during the main phase of Deccan flood basalt volcanism generated an only moderate climate change, as discussed in Schulte et al. (2010). However, the most significant point is that the extinction pattern observed in the foraminifera does not match this type of cause, as in this case it would have been gradual rather than massive and sudden. Furthermore, no other major extinctions have been observed that coincide with the 364 peak of volcanic activity, which is prior to the $\mathrm{K} / \mathrm{Pg}$ boundary. Many 365 other causes have been put forward, among which eustatic changes 366 is a frequent contender, but this does not adequately explain the mass 367 extinction in pelagic marine ecosystems and even less in continental 368 environments (Brusatte et al., 2014).

\section{The Paleocene/Eocene boundary event}

The Paleocene/Eocene $(\mathrm{P} / \mathrm{E})$ boundary has been defined in the 371 Dababiya section (Egypt) and is dated to $56.0 \mathrm{Ma}$ (Aubry et al., 2007; 372 Vandenberghe et al., 2012). The criterion used is a negative anomaly of 373 the $\partial^{13} \mathrm{C}$, the base of this anomaly corresponding to a major crisis in 374 the smaller abyssal and bathyal foraminifera. This crisis is one of the 375 most significant in the history of the small benthic foraminifera that 376 lived in the bathyal and abyssal marine environments (Kennett and Q5 Stott, 1991; Thomas and Shackleton, 1996). It seems to have been caused 378 by a massive increase in the ocean temperature (Owen and Rea, 1992; 379 Sloan et al., 1992), and/or by multiple environmental changes, including 380 decreased carbonate saturation, ocean acidification, lowered oxygen 381 levels, and a globally reduced food supply, all related to a massive carbon 382 injection (Winguth et al., 2012). The P/E boundary event coincides with 383 the Paleocene-Eocene Thermal Maximum (PETM), the major Cenozoic 384 global warming event. This event was identified in various sections in 385 Spain (Canudo and Molina, 1992; Molina et al., 1994; Arenillas and 386 Molina, 1996; Orue-Etxebarria et al., 1996, 2004).

The PETM triggered effects in continental environments that have 388 been known not for the extinctions but for the great diversity of terres- 389 trial flora and fauna. In the 19th century, Lemoine and later specialists in 390 fossil vertebrates in the 20th century, such as Teilhard de Chardin, and 391 Russell, drew attention to the existence near the P/E boundary of a 392 great evolutionary radiation of mammals, known as the "mammal dis- 393 persion event" (Bowen et al., 2002). During this event, some Paleocene 394 faunas became extinct, whereas the modern orders of mammals 395 (Artiodactyla, Perissodactyla and Primates) first appeared at the P/E 396 boundary (Gingerich, 2006). From then on, large mammals evolved 397 and occupied many of the ecological niches that the dinosaurs had left 398 vacant. Furthermore, there was an extensive migration of tropical and 399 sub-tropical species to colder latitudes. The tropical-subtropical vegeta- 400 tion consisting mostly of tropical rainforest species extended towards 401 the poles up to $50-60^{\circ}$ latitude. The geographical distributions of or- 402 ganisms were radically rearranged by $5-8{ }^{\circ} \mathrm{C}$ of warming. Tropical spe- 403 cies moved poleward both in marine and terrestrial realms (McInerney 404 and Wing, 2011).

These migrations to higher latitudes have also been identified in 406 marine environments. The planktic foraminifera diversified rapidly; 407 Acarinina sibaiyaenis and Acarinina africana reached their apogee 408 (Fig. 3). A significant migration of tropical species into higher latitudes 409 has been documented in several sections in Spain (Canudo et al., 410 1995; Arenillas and Molina, 1996; Arenillas et al., 1999; Molina et al., 411 1999). Something similar occurred with the dinoflagellates, which 412 reached an apogee of the genus Apectodinium, and the calcareous 413 nannofossils which underwent a marked process of diversification. 414 Moreover, in platform environments, the larger foraminifera (e.g., 415 Nummulites, Alveolina) diversified and many of them increased in size 416 at the base of the Ilerdian (Orue-Etxebarria et al., 2001).

The study of a number of sections in the Iberian Peninsula has been 418 crucial for a full understanding of the P/E event. In the Alamedilla, 419 Caravaca, and Zumaya sections, a distinct clay layer is overlying the 420 rapid but gradual mass extinction of the small benthic foraminifera 421 (Lu et al., 1996; Schmitz et al., 1997; Alegret et al., 2005b, 2009; Zili 422 et al., 2009; Alegret et al., 2010). In addition, this study is based also 423 on sections in Possagno (Italy) and Dababiya (Egypt). The Spanish sec- 424 tions are very continuous and have been useful for a detailed study of 425 the Paleocene/Eocene event, but the stratotype of the P/E boundary 426 was finally defined in the Dababiya section, near Luxor (Egypt). 
The group most affected by this event was the smaller benthic foraminifera in bathyal and abyssal oceanic environments, which suffered a crisis that can be considered a rapid mass extinction. The most representative section for this crisis is that of Alamedilla, which is where the levels that record the extinction event have been studied in the greatest detail (Fig. 4; Alegret et al., 2009, 2010). In this section, 37\% of the species of benthic foraminifera became extinct in a $30 \mathrm{~cm}$ interval of marly sediments, coinciding with the onset of the Carbon Isotopic Excursion (CIE). The taxa which went extinct in the deep marine environments at Alamedilla are K-selection strategists, such as A. avnimelechi, Anomalinoides rubiginosus, A. truncata, B. delicatulus, C. hyphalus, $C$. howelli, C. velascoensis, Coryphostoma midwayensis, Dorothia pupa, Gyroidinoides subangulatus, Marsonella oxycona, Neoflabellina jarvisi, Nuttallinella florealis, Osangularia velascoensis, Pullenia coryelly, and $S$. beccariiformis. These taxa were principally species with calcitic tests, some of which had survived the crisis at the K/Pg boundary. Only few of these species have been recorded from sections deposited in shallower environments (e.g., Dababiya). Among those that became extinct we must mention A. avnimelechi, which is the most characteristic of these habitats.

An example of a delayed extinction taxa is Anomalinoides aegyptiacus, as can be observed in the Dababiya section (Alegret et al., 2005b). This species is regarded by Speijer et al. (2000) as an opportunistic taxon that temporarily migrated basin-downwards to greater depths during the PETM and later repopulated the vacant outer shelf ecosystem. The disaster taxa in this event, in which the dissolution of carbonates appears to have been a decisive factor, were those with agglutinated shells that grew significantly larger as they faced less competition for trophic resources and could live in environments below the calcite dissolution level. In Alamedilla, the taxa Repmanina (Glomospira) charoides and Glomospira spp., commonly known as Glomospira Acme, are abundant. In deeper shelf environments (e.g., Dababiya), where benthic foraminifera were less affected, we find Aragonia aragonensis, whose apogee could be considered to be an indicator of hyperthemal events, although this species is rarely recorded in Egyptian shelf settings and it is difficult to evaluate its ecostratigraphic meaning. In Alamedilla, opportunist taxa appear after the disaster taxa. These are calcareous r-selection strategists, and the dominant species are Globocassidulina subglobosa $(<45 \%$ of the assemblages), Nuttallides truempyi, Osangularia spp., Tappanina selmensis, O. umbonatus, Reusella terquemi, A. aragonensis, Abyssamina quadrata, and Quadrimorphina profunda. Once the environment has recovered and the levels of $\mathrm{CaCO}_{3}$ have been restored, the recovery progenitor taxa made their appearance. In Alamedilla, N. truempyi and Osangularia spp., the buliminids, Pleurostomella spp., and Stilostomella spp. are abundant (Alegret et al., 2009). The pioneer progenitor taxon may be taken to have been Turrilina brevispira in Dababiya. Lazarus taxa were very frequent, since a large number of species with calcitic tests re-emerged when normal environmental conditions returned, for instance N. truempyi, C. pseudoacutus, and Bulimina midwayensis, which can be considered as K-selection strategists.

The P/E extinction event was very brief, as it is represented by 30 to $50 \mathrm{~cm}$-thick clays in the sections (e.g., Zumaya, Alamedilla, and Caravaca), which represents a period of approximately $0.01 \mathrm{Myr}$ (Alegret et al., 2010). Therefore, this is a relatively rapid but gradual mass extinction pattern produced by the hyperthermal event. The survival phase is represented by a clay interval of variable thickness (approximately $1 \mathrm{~m}$ in Alamedilla and Caravaca to $4 \mathrm{~m}$ in Zumaya). The recovery phase was relatively brief, as environmental conditions returned to normal relatively quickly and many species survived the event. This phase ended when migrations to higher latitudes and the apogee of Acarinina ceased, witnessing a return to normal temperatures.

Oxygen isotope analysis shows that at the P-E transition the greatest increase in temperature of the entire Cenozoic occurred (Zachos et al., 2001, 2008). Moreover, just at the P/E boundary there was a far greater increase in temperature, leading to a hyperthermal event (Thomas and Zachos, 2000; Zachos et al., 2001; Thomas, 2003, 2007; Zachos et al.,
2008; McInerney and Wing, 2011; Speijer et al., 2012). The most plausi- 494 ble explanation is that it was linked to plate tectonics, on the one hand 495 the opening up of the North Atlantic, which generated a large igneous 496 province (Norwegian-Arctic volcanism) and additionally the closure 497 of the Tethys due to the progressive displacement of the Indian plate to- 498 wards the Asiatic and the African towards the European plates. Thus the 499 triggering mechanism could have been as follows: North-Atlantic rifting 500 generated volcanic activity, injecting $\mathrm{CO}_{2}$, starting a global warming, 501 Indian rifting restricted the Tethys current and increased the salinity 502 of this sea, modifying the global marine currents and shifting towards 503 from a thermohaline circulation system to a halothermal one. This pro- 504 duced an increase in temperature in marine depths that destabilized 505 methane hydrates, a large amount of methane gas was released and 506 hence of organic carbon ${ }^{12} \mathrm{C}$, entering the atmosphere together with 507 $\mathrm{CO}_{2}$ resulting from the oxidation process, leading to an extreme green- 508 house effect (Dickens et al., 1997; Svensen et al., 2004). As a result of 509 the greenhouse effect, the highest average global temperature of the 510 Cenozoic was reached. The strongly negative excursion of the carbon 511 isotopes indicates that large quantities of organic carbon were released 512 into oceanic and atmospheric reservoirs. Methane and carbon dioxide 513 produced an intense greenhouse effect and a sudden increase in tem- 514 perature, giving rise to the P/E hyperthermal event. The ocean depths 515 became anoxic or hypoxic and the calcite compensation level rose by 516 several hundred meters. This generated the deposition of a thick layer 517 of shale at the P/E boundary. It is in the underlying marly levels that 518 we find the extinction of the small bathyal and abyssal benthic forami- 519 nifera, and it is plausible to trace a cause-effect relationship between 520 the hyperthermal event, the anoxia, the shallowing of the calcite com- 521 pensation depth and the extinction of the bathyal and abyssal benthic 522 foraminifera.

Among the possible triggers of this extinction event some authors 524 have proposed that it was due to an extraterrestrial impact. One of the 525 main arguments in favor of this hypothesis is the presence of a small 526 and enigmatic iridium anomaly in the Zumaya section found by us 527 (Schmitz et al., 1997), which some researchers (Kent et al., 2003) have 528 interpreted as the result of a comet impact. However, at the level 529 of the anomaly, both in Zumaya and in Alamedilla, there has been 530 an intense search for additional evidence of an extraterrestrial im- 531 pact (e.g., Ni-rich spinels, microtektites) but none have been found 532 (Schmitz et al., 2004). The most convincing evidence is that there is 533 no correlation between the small iridium anomaly and the extinction 534 interval of the benthic foraminifera, as the small, enigmatic iridium 535 anomaly occurred $40 \mathrm{~cm}$ below in the section. On the other hand, the 536 extinction coincides with the carbon and oxygen isotopic changes and 537 it would appear more plausible to attribute the extinction of the bathyal 538 and smaller abyssal foraminifera to the sudden hyperthermal heating of 539 the deep ocean.

\section{Middle-Late Eocene transition event}

The Late Eocene was a turbulent time, but two events stand out: the 542 late Bartonian photosymbiotic crisis and the Early Rupelian cooling 543 event Oi-1 (McGowran, 2012). Between the Middle-Late Eocene transi- 544 tion and the Eocene/Oligocene boundary, various events occurred which 545 affected many groups of organisms, both marine and continental. In gen- 546 eral terms, this could be considered to have been a long-term gradual 547 mass extinction event (Kaiho, 1994), which would have lasted more 548 than $6 \mathrm{Myr}$, from the Mid-Eocene to the Early Oligocene, and it is usually 549 related to a prolonged decline in global temperature (Zachos et al., 550 2001). However, it is useful to analyze three events separately: the 551 Middle-Late Eocene transition extinction event, the Eocene/Oligocene 552 boundary extinction event, and, the Mid-Priabonian meteorite impacts. 553 Furthermore, a single gradual mass extinction lasting more than 6 Myr 554 seems inappropriate and according to our data (Gonzalvo and Molina, 555 1992, 1996; Molina, 2006, 2007), two separate extinction events seem Q8 more plausible. 
Little is known about the chronology of the extinction event near the Bartonian/Priabonian (B/P) boundary, as the boundary stratotype between these two stages has not yet been officially defined: the base of the Priabonian is still unclear but in terms of absolute dating the boundary is placed at around $37.8 \mathrm{Ma}$ (e.g., Vandenberghe et al. in The Geologic Time Scale) (Gradstein et al., 2012). The end of this extinction event used to be placed at the $\mathrm{B} / \mathrm{P}$ boundary, but recently it has been proposed to locate it in a higher lithostratigraphic horizon at Alano, Italy (Vandenberghe et al., 2012). The planktic foraminifera suffered one of the major crises of their history, after the largest one, which occurred at the $\mathrm{K} / \mathrm{Pg}$ boundary. The effect of this event on other groups is less well known, with the mollusks being one of the groups most seriously affected: on the west coast of North America, $100 \%$ of tropical species disappeared (Hickman, 2003). The radiolaria were also greatly affected, suffering a slow gradual mass extinction along Chron 17, from the middle part of the RP16 biozone to the top of the RP17 biozone (Kamikuri and Wade, 2012), lasting almost 2 Myr.

The sections we studied are located mainly in the Pyrenees (Arguis and Artieda) and in the Betic Cordillera (Torre Cardela and Aspe). In addition, we studied various boreholes of the DSDP-ODP, especially at Site 94 and Site 612 in the Atlantic Ocean. These sites show a hiatus right at the Middle-Late Eocene transition (Molina et al., 1993), which hinders a detailed study of the extinction pattern of the foraminifera, but which allows us to know what happened in between the two extinction events. The best section that has been studied, which may be considered the reference section, is the Torre Cardela section in the Betics (Gonzalvo and Molina, 1992, 1996). It illustrates very clearly the slow gradual extinction pattern, the duration of its phases and the survival strategies of the planktic foraminiferal species.

In sub-tropical latitudes, where the Torre Cardela section was located, there was an extinction of the spinose and other tropical species (Fig. 5). This involved the extinction of almost three genera (Orbulinoides, Morozovelloides, and most species of Acarinina) and the specific richness was reduced by 33\%. Most of the extinct species were large spinose forms, with a carinated periphery and muricated wall: Acarinina bulbrooki, Acarinina topilensis, Acarinina primitiva, Acarinina rohri, Morozovelloides lehneri, and Morozovelloides crassatus. Furthermore, the extinction involved other species such as Orbulinoides beckmanni, Hantkenina liebusi, Hantkenina dumblei, Globigerinatheka kugleri, Globigerinatheka subconglobata, and Turborotalia altispiroides. In addition, there is another species (Acarinina collactea) that may be considered a delayed extinction species.

The disaster taxa are hard to identify. Some species such as Dentoglobigerina eocaena and Globorotaloides suteri reached their acme in the survival stage and would appear to be the disaster species, which if true would mean that those that survived were the larger forms, unlike what occurred at the $\mathrm{K} / \mathrm{Pg}$ boundary. We may consider Hantkenina alabamensis, which inhabited warmer latitudes, to be a Lazarus species. Its temporary absence reflects a fall in temperature during the event. The survivor taxa predominate and include the most cosmopolitan forms; among the most characteristic ones are: Subbotina hagni, Subbotina linaperta, Pseudohastigerina micra, Streptochilus martini, Chiloguembelina cubensis, and Dentoglobigerina corpulenta.

The extinction stage is likely to extend from the disappearance of 0 . beckmanni, in the upper part of the $\mathrm{E} 12$ biozone, to the disappearance of $M$. crassatus, at the top of the E13 biozone (Gonzalvo and Molina, 1992, 1996). The long extinction stage extended over $35 \mathrm{~m}$ of marly sediments. It may have lasted some $2 \mathrm{Myr}$, according to the calibration of zone E13 by Wade et al. (2011) and is considered a slow mass extinction event. The extinction pattern shows two main steps at the beginning and at the end, the extinction of the spinose carinate species being the most significant.

The trigger of the extinction event could have been the separation of the Antarctic, American, and Australian plates, causing the isolation of Antarctica by the opening of the Drake Passage, with the consequent emergence of a current around the Antarctic. The warm currents from the tropical Atlantic and Pacific oceans ceased, and a circum-Antarctic 624 current may have led to a permanent ice cap at the South Pole; the accu- 625 mulation of ice and snow would have generated an albedo effect, which 626 would have caused a fall in the planet's average temperature. The $\partial^{18} \mathrm{O} 627$ suffered a sharp decline and indicates the onset of the Antarctic glacia- 628 tion (Shackleton and Kennett, 1975; Livermore et al., 2005; Tripati 629 et al., 2005). The $\partial^{13} \mathrm{C}$ values, meanwhile, show a slight reduction in pro- 630 ductivity. While the extinctions of the carinate spinose species occur 631 during a long-term cooling trend, the biotic turnover in the muricate 632 group could not be related to significant climatic changes, according to 633 Wade (2004), who proposed that this turnover event was probably re- 634 lated to the increased surface water productivity and the deterioration 635 of photosymbiotic partnerships with algae.

No evidence of meteorite impacts has been reported for the time in- 637 terval of the Middle/Late Eocene boundary extinction event, although 638 some researchers (Alvarez et al., 1982) on the basis of imprecise corre- 639 lations have suggested that such impacts might have been the cause. 640 Hence, the geological cause discussed in the preceding paragraph is in 641 our view the most plausible one; as it explains the origin of the global 642 cooling that would have caused the gradual extinction of the most spe- 643 cialized species of planktic foraminifera that were adapted to warm 644 environments. In addition, this cause is a highly plausible explanation 645 for the severe crisis experienced by radiolarians and tropical mollusks, 646 although mollusks were probably regulated by the combined effect of 647 cooling and sea-level fall, while radiolarians and planktic foraminifera 648 were mostly regulated by the cooling of the ocean surface waters.

\section{Eocene/Oligocene extinction event}

The planktic foraminifera extinction event has served as a criterion 651 for the definition of the Eocene/Oligocene (E/O) boundary. It coincides 652 with the Priabonian/Rupelian boundary and has been dated to 653 33.9 Ma (Vandenberghe et al., 2012). The extinction of the last 654 hantkeninids is the principal criterion for its correlation and characteri- 655 zation (Premoli Silva et al., 1988) while the stratotype (GSSP) of the E/O 656 boundary has been formally defined in the section of Massignano, Italy 657 (Premoli Silva and Jenkins, 1993). Previously, the Spanish sections of 658 Torre Cardela, Molino de Cobo and Fuente Caldera (Molina, 1986) had 659 been proposed as candidates. They are a richer source of data on the 660 Eocene-Oligocene transition, allowing to study the extinction process 661 of the planktic foraminifera with a higher resolution than in the official 662 boundary stratotype. In addition, we have studied sites of the DSDP- 663 ODP. The latter tend to be affected by condensation, hiatuses, and disso- 664 lution, but in sites 219 and 292 the Eocene/Oligocene boundary is re- 665 corded and the foraminifera are very well preserved (Molina et al., 666 1993). One of the best sections in the world is located in Tanzania, 667 which allowed Wade and Pearson (2008) and Pearson et al. (2013) to 668 conclude that the E/O boundary is located between two principal 669 steps in the stable-isotope records and that the extinction of the 670 hantkeninids preceded the maximum glacial conditions in the early 671 Oligocene by approximately $200 \mathrm{kyr}$.

Among the most emblematic groups that were greatly affected by 673 this extinction event were the mammals. They underwent a major 674 renovation that is very well documented in Europe, where it is known 675 as Stehlins "grande coupure", which meant a major turnover in the 676 mammalian fauna. This involved the extinction of most of the endemic 677 European mammalian taxa, to be replaced by species migrating from 678 Asia, a process that also affected other fauna and flora (Hartenberger, 679 1998). The cause of these changes would appear to be directly related 680 to the closure of the Turgai Strait, with the consequent linking of 681 Europe and Asia, thereby putting an end to the paleogeographical isola- 682 tion of Europe and permitting migrations of species from one continent 683 to the other (Prothero, 1994). On the west coast of the United States, 684 evidence has been found of another sudden extinction of mollusks 685 (Hickman, 2003). Foraminifera and mollusk extinctions seem to be 686 more closely linked to the Oi-1 cooling event. 
The reference section for the study of the planktic foraminifera is Fuente Caldera (Fig. 6; Molina, 1986; Molina et al., 2006b; Alegret et al., 2008), The boundary interval is also well exposed and extensive in Torre Cardela (Martínez Gallego and Molina, 1975) and Molino de Cobo (Molina et al., 1988). The figures included in the papers cited clearly show the duration of the phases, the extinction pattern and survival strategies of the species involved. The event is characterized by the extinction of the hantkeninids and turborotalids. Three genera became extinct: Hantkenina, Cribrohantkenina, and Turborotalia. The species that became extinct gradually account for $31 \%$ of the assemblages. They are: Turborotalia cocoaensis, Turborotalia cunialensis, Hantkenina primitiva, Hantkenina compressa, H. alabamensis, Hantkenina nanggulanensis, and Cribrohantkenina lazzarii. In addition, P. micra s.str. also seems to have gone extinct since the surviving morphotypes that have been assigned to this species are much smaller. It is very likely that they belong to a different species (Lilliput effect).

Subbotina yeguaensis and the small species Pseudohastigerina naguewichiensis may be considered delayed extinctions. Species whose prevalence increased and may thus be considered disaster species are Subbotina gortanii and G. suteri. The progenitor species Tenutitella gemma, Tenuitella neoclemenciae, and Tenuitellinata angustiumbilicata are of small size and have a micro-perforated wall. Lazarus species are rare and the only one identified so far is Subbotina angiporoides. The survivor taxa are the majority and include the most cosmopolitan forms, among them quite a few of those that also survived the Bartonian-Priabonian extinction: S. linaperta, C. cubensis, D. eocaena, and Catapsydrax unicavus. The extinction phase begins with the disappearance of Turborotalia cocoaensis and concludes with that of C. lazzarii. This stage was quite brief, it is recorded in $1.2 \mathrm{~m}$ of claymarly sediments and may have a duration of some $0.04 \mathrm{Myr}$, according to the calibration of Wade et al. (2011). It is considered a rapid mass extinction event. In some more condensed sections such as Massignano (Gonzalvo and Molina, 1992) this stage it is more difficult to identify.

The trigger of this extinction event must have been the same that caused the progressive cooling culminating in the basal Oligocene Oi-1 glaciation. The emergence of the circum-Antarctic current would have triggered the prolonged cooling across the Late Eocene, and given rise to the forming of an ice cap in the Antarctic and to the psycrosphere, culminating in the global glaciation Oi- 1 near the $\mathrm{E} / \mathrm{O}$ boundary (Kennett and Schackleton, 1976). Another interpretation is that the Oi-1 was caused by a threshold response to long-term Cenozoic decline in atmospheric carbon dioxide levels (DeConto and Pollard, 2003; Pearson et al., 2009). Furthermore, the deepening of the calcite compensation depth was synchronous with the stepwise onset of Antarctic ice-sheet growth (Coxall et al., 2005). The extinction pattern is very similar to that at the B-P transition, with most of the warm-water species disappearing, some of which had managed to survive the previous event. Therefore, in the basal Oligocene the very low diversification of the fauna was limited to temperate and cold waters. Consequently, the cause that triggered this extinction event would have been a new switch to cooler climates as well. The planktic foraminifera extinction event occurs approximately 200 kyr prior to the Oi- 1 glaciation and the subsequent sea level fall (Coxall et al., 2005), indicating that the cause of the extinction was the cooling, rather than the fall of the sea level fall.

No evidence of a meteorite impact has been found coinciding with the extinction event at the E/O boundary. Evidence of the impact in the Mid-Priabonian has been well known since the discovery of microtektites in the Caribbean and the Gulf of Mexico (Glass et al., 1973). Moreover, the discovery of an iridium anomaly led some researchers to suggest an impact around $34 \mathrm{Ma}$ and to associate this with the extinction at the end of the Eocene (Alvarez et al., 1982; Ganapathy, 1982). The microtektites extend across the North Atlantic, as shown by numerous sites of the DSDP-ODP (Keller et al., 1987; Molina et al., 1993). A number of studies show that the impacts occurred earlier than the extinctions, and some researchers have proposed a mass stepwise extinction pattern during the Late Eocene, attributing the stages of extinction to comet or meteorite impacts (Hut et al., 754 1987; Kauffman, 1988). In the Massignano (Italy) section, three layers 755 of iridium have been identified (Montanari et al., 1993) whereas in 756 most DSDP-ODP sites there are just one, two, or at most three levels 757 of microtektites. However, Hazel (1989), using graphic correlation tech- 758 niques, concluded that there are at least six impact levels. The study of 759 sites in the Atlantic, Indian and Pacific Oceans, together with the Italian 760 and Spanish sections, has enabled us to reduce the possible impact 761 levels to three, which were dated precisely based on the presence 762 of planktic foraminifera, finding that they did not coincide with the 763 extinction (Gonzalvo and Molina, 1992). Therefore these impacts did 764 not cause the extinctions of the planktic foraminifera (Molina et al., 765 1993, 2006b).

Evidence of meteorite impacts has been found, such as quartzes 767 with impact metamorphosis (Clymer et al., 1996) and Ni-rich spinels 768 (Pierrard et al., 1998; Robin and Molina, 2006; Molina et al., 2006b). 769 Several impact craters dated as Mid-Priabonian have been located, 770 such as Popigai in Siberia with a diameter of $100 \mathrm{~km}$ (Bottomley et al., 771 1993), Chesapeake Bay on the eastern continental platform of North 772 America with a diameter of $90 \mathrm{~km}$ (Koeberl et al., 1996), and Toms 773 Canyon, also on the eastern platform of North America with a diameter 774 of $20 \mathrm{~km}$. The correlation of these impact craters with the ejected mate- 775 rial deposits has been established by Poag et al. (2003), confirming the 776 impact of three large meteorites around 35.6 Ma.

777

These data confirm that there is no correlation between levels with 778 evidence of impacts and levels with extinctions, as the extinctions 779 occurred in the Middle-Late Eocene transition and at the Eocene/ 780 Oligocene boundary, whereas the evidence of impacts is in the Mid- 781 Priabonian. Therefore, there is no coincidence and no cause-effect rela- 782 tionship can be established between impacts and extinctions. Some re- 783 searchers have suggested that global cooling may have been accelerated 784 by the impacts (Wonhof et al., 2000), but the isotopic data do not sup- 785 port any acceleration (Livermore et al., 2005). It seems evident, then, 786 that the meteorites were not large enough to cause a global catastrophe. 787

The Mid-Priabonian impacts, which due to their proximity to one 788 another were hitherto interpreted as a single event that supposedly 789 caused a massive extinction, constitute a key argument next to the 790 $\mathrm{K} / \mathrm{Pg}$ boundary for proponents of periodicity in extinction events. 791 There has been a great debate on the subject of periodicity in extinction 792 events, since periodicity implies that all extinction events were trig- 793 gered by meteorite impacts. The first to put forward the notion of 794 periodicity were Fischer and Arthur (1977) who proposed a cyclical 795 period of $32 \mathrm{Ma}$, but the debate did not commence in earnest until 796 Raup and Sepkoski (1984) suggested a periodicity of $26 \mathrm{Ma}$. Some sup- 797 porters of this hypothesis went so far as to suggest that Nemesis, a sup- 798 posed twin star of our Sun, passes periodically through the Oort cloud 799 causing a shower of meteorites to fall on the Earth (Hut et al., 1987). 800 However, recent high-resolution studies of the geological time scale 801 (Vandenberghe et al., 2012) allow us to rule out this supposed periodic- 802 ity, since at least the Paleogene events presented here do not show any 803 periodicity because they occurred at 66.04, 56.0, 37.8 and 33.9 Ma. 804

\section{Discussion and conclusions}

The planktic foraminifera reached the zenith of their diversity in the 806 Late Cretaceous and suffered the greatest crisis in their history at the 807 $\mathrm{K} / \mathrm{Pg}$ boundary, after which they recovered and flourished again during 808 the Early and Mid-Eocene climatic optimum, although their specific di- 809 versity was never as great as it had been in the Late Cretaceous. From 810 the Mid-Eocene onward, their diversity started to decline with the ex- 811 tinction of the species with the most complex morphology that had 812 adapted to warmer waters. As a result, the Early Oligocene was a period 813 with very low diversity of planktic foraminifera and this coincides with 814 the coldest climate of the Paleogene. The species that disappeared 815 in these various extinction events were the most highly specialized 816 K-selection strategists, those adapted to the deepest environments 817 


\begin{tabular}{|c|c|c|c|c|}
\hline EXTINCTION EVENTS & $\begin{array}{l}\text { Cretaceous/Paleogene } \\
\text { Maastrichtian/Danian }\end{array}$ & $\begin{array}{l}\text { Paleocene/Eocene } \\
\text { Thanetian/Ypresian }\end{array}$ & $\begin{array}{l}\text { Middle/Upper Eocene } \\
\text { Bartonian/Priabonian }\end{array}$ & $\begin{array}{l}\text { Eocene/Oligocene } \\
\text { Priabonian/Rupelian }\end{array}$ \\
\hline Absolute age & $\mathrm{K} / \mathrm{Pg}=66.04 \mathrm{Ma}$. & $\mathrm{P} / \mathrm{E}=56.0 \mathrm{Ma}$ & $\mathrm{B} / \mathrm{P}-$ Around $37.8 \mathrm{Ma}$ & $\mathrm{E} / \mathrm{O}=33.9 \mathrm{Ma}$ \\
\hline Reference section studied & El Kef & Alamedilla & Torre Cardela & Fuente Caldera \\
\hline Spanish sections studied & Caravaca, Zumaya, Agost & Alamedilla, Caravaca, Zumaya & Aspe, Artieda, Arguis, Torre Cardela & Fuente Cardera, Torre C., Molino Cobo. \\
\hline Other sections studied & In Tunisia, Mexico, Cuba, France & Possagno (Italy), Dababiya (Egypt) & ODP-DSDP (13 sites) & Massignano (Italy), ODP-DSDP (11 sites) \\
\hline Estraterrestrial causes & Meteorite impact $>10 \mathrm{~km}$ & Comet? & Not simultaneous with event & Not simultaneous with event \\
\hline Extraterrestrial evidences & Ir, microtectite, spinel, shocked Q & Small enigmatic Ir anomaly at Zumaya & Not found just at the event & Not found just at the event \\
\hline Impact craters & Chicxulub & Not found & Not found just at the event & Not found just at the event \\
\hline Geological causes & Not found & Opening of North Atlantic & Isolation of Antarctica (Circumant. current) & Closure of Turgai strait (Europe-Asia) \\
\hline Large Igneous Provinces & Deccan volcanism & Norwegian-Artic volcanism & Not found & Not found \\
\hline Geological evidence & Megaturbidite and dark grey clay & Red or grey clay (calcite dissolution) & Grey clay & Grey clay \\
\hline Eustatic factor & Sea level fall? & Sea level fall and rise & Possible sea level fall & Sea level fall \\
\hline Temperature factor & Abrupt oscillation & Hyperthermal event (Ice house effect) & Strong gradual decrease & Very fast decrease \\
\hline Chemical factors & Strangelove ocean, acid rain & Anoxia, methane hydrates release & $\mathrm{CO}_{2}$ low & $\mathrm{CO}_{2}$ low \\
\hline Productivity factor & Strong decrease of $\partial^{13} \mathrm{C}$ & Strong decrease of $\partial^{13} \mathrm{C}$ & Low decrease of $\partial^{13} \mathrm{C}$ & Low decrease of $\partial^{13} \mathrm{C}$ \\
\hline Most affected environments & Terrestrial and pelagic & Bathyal and abyssal & Neritic and pelagic & Terrestrial and pelagic \\
\hline Biological causes & No time for natural selection & High competition and selection & Moderate competition and selection & High competition and selection \\
\hline Most affected organisms & Dinosaurs, ammon., belemn., rudist. & Smaller benthic foraminifers & Tropical molluscs and radiolarians & Mammals ("Grand coupure") \\
\hline Extinction pattern & Sudden (Globotruncanids) & Rapid (Smaller benthic forams) & Slow (spinose carinated forms) & Rapid (Hantkeninids \& Turborotalids) \\
\hline Species extinction & 91\% (Planktic forams) & $>37 \%$ (Smaller benthic forams) & $33 \%$ (Planktic forams) & $31 \%$ (Planktic forams) \\
\hline Extinct taxa & 56 (G. arca, A. mayaronensis, etc.) & $>25$ (A. avnimelechi, A. rubiginosus, etc.) & 12 (O. beckmanni, M. crassatus, etc.) & 8 (T. cunialensis, H. alabamensis, etc.) \\
\hline Delayed extinct taxa & Hedbergella holmdelensis, etc. & Anomalinoides aegyptiacus, etc. & Acarinina collactea \& G. subconglobata & S. yeguaensis \& Pseudohastigerina $<100 \mu \mathrm{m}$ \\
\hline Disaster taxa & Rugoblobigerina cretacea, etc. & Agglutinated forams (Glomospira spp.) & Subbotina eocaena \& Globorotaloides suteri & Subbotina gortanii \& Globorotaloides suteri \\
\hline Opportunistic taxa & Guembelitria cretacea, etc. & G. subglobosa, T. selmensis, etc. & Turborotalia cocoaensis, G. semiinvoluta, etc & c.Tenuitella gemma, etc. \\
\hline Progenitor taxa & Paleoglobigerina alticonusa, etc. & Turrilina brevispira, etc. & Globigerinatheka luterbacheri, etc. & Tenuitella gemma, etc. \\
\hline Lazarous taxa & Numerous smaller benthic forams & Calcitics forams & Hantkenina alabamensis, etc. & Subbotina angiporoides, etc. \\
\hline Survivor taxa & Zeuvigerina waiparaensis, etc. & Nuttallides truempyi, etc. & Subbotina hagni, Subbotina linaperta, etc. & Dentoglobigerina eocaena, etc. \\
\hline Extinction interval & Extremely short (years or decades) & Short (0.01 Myr) & Long (2 Myr) & Short (0.04 Myr) \\
\hline
\end{tabular}

Fig. 7. Comparative synthesis of the main Paleogene mass extinction events.

and living in the warmest latitudes. After the extinction events, the generalized r-selection strategists predominated and gradually specialized again and recolonized the deepest habitats. Consequently, we find an alternation of polytaxic periods with large numbers of specialized species (Late Cretaceous, Late Paleocene-Mid Eocene) and oligotaxic periods with small numbers of generalistic species (Early Paleocene and Early Oligocene).

The extinction events in the Paleogene (K/Pg boundary, $\mathrm{P} / \mathrm{E}$ boundary, B/P transition, E/O boundary) occurred at 66.04, 56.0, 37.8, and 33.9 Ma, respectively and, therefore, do not fit into periodic extinction models (Fig. 7). Evidence of meteorite impacts indicates that the greatest meteorite impacts occurred at 66.04 and around $35 \mathrm{Ma}$. The large meteorite impacts were mass extinction triggers, as at the $\mathrm{K} / \mathrm{Pg}$ boundary. However, there are no other mass extinction events during the Paleogene for which a cause-effect relationship can be traced between meteorite impacts and mass extinctions.

The examples presented in this study indicate that the causes are different for each extinction event. However, the temperature factor proves to be the most relevant and omnipresent one: global falls in water temperature tend to lead to extinction while temperature increases tend to result in greater diversity of species. Since the tropics have a greater abundance of specialized forms, these zones become a lethal trap during global falls in temperature: the species that inhabit them cannot migrate to maintain their optimal temperature, unless they colonize deeper niches, though this phenomenon requires some time for evolution to enable adaptation to greater hydrostatic pressure. In contrast, increases in temperature can be overcome mainly by migration of species to higher latitudes. In some environments, the increase in temperature may also lead to extinctions, as occurred in the deep ocean at the P/E boundary.

In general, there are three kinds of triggers for mass extinctions: biological, geological and extra-terrestrial. Biological causes (competition, endemism) operate mainly at the level of background extinction, while mass extinctions tend to be triggered by geological causes (e.g., plate tectonics generating volcanic activity, greenhouse effect, glaciations, 851 and eustatic sea-level) and by extra-terrestrial causes (e.g., large mete- 852 orite or comet impacts and possibly cosmic and solar radiation). 853

The terminology generally used to name patterns of mass extinction 854 (gradual, step-wise, catastrophic) is imprecise and does not reflect 855 well enough the processes involved. The step-wise mass extinction pat- 856 tern, which was proposed for extinctions in the Late Eocene and was 857 supposedly produced by a series of meteorite or comet showers, has 858 been refuted (see above). The step-wise pattern could be the result of 859 conflating different events or it could amount to one slow extinction 860 pattern that may not have been constant in its intensity. Hence, a new 861 terminology is proposed: sudden mass extinction, rapid mass extinc- 862 tion, and slow mass extinction. According to the events in our study, 863 sudden mass extinction would have occurred almost instantaneously, 864 the process taking just years or decades (K/Pg boundary). This can 865 only be confirmed by studies of continuous and expanded sections. 866 Rapid mass extinction is characteristic of events of relatively short dura- 867 tion of around $100 \mathrm{kyr}(\mathrm{P} / \mathrm{E}$ and $\mathrm{E} / \mathrm{O}$ boundaries) and can be best ob- 868 served in continuous and data-rich sections, while in more condensed 869 sections it may appear to have been sudden. Finally, slow mass extinc- 870 tion would take around $1 \mathrm{Myr}$ (B/P transition) and could extend even 871 to a few million years.

$$
872
$$

\section{Uncited references}

Arenillas et al., 2002

Conzalvo and Molina, 1996

Molina et al., 2002

\section{Acknowledgments}

I thank the members of my Micropaleontology group (L. Alegret, 878 I. Arenillas, J.A. Arz, J.I. Canudo, L.E. Cruz, R. Fenero, C. Gonzalvo and 879 
S. Ortiz) that were my coauthors in the publications on which this review paper is mainly based, and from which new results emerge about the patterns and causes of the main extinction events in the Paleogene. This study has been conducted within the framework of the projects CGL2011-23077 and CGL2011-22912 of the Spanish Ministry of Science and Technology (FEDER funds) and the consolidated group E05 funded by the Government of Aragon. I would also like to thank Brian McGowran (University of Adelaide, Australia), Paul Pearson (Cardiff University, UK), Hanspeter Luterbacher (University of Tübingen, Germany), and an anonymous reviewer for their critical comments on an earlier draft, which have enhanced the final result.

\section{References}

Alegret, L., Arenillas, I., Arz, J.A., Molina, E., 2002. Environmental changes triggered by the $\mathrm{K} / \mathrm{T}$ impact event at Coxquihui (Mexico) based on foraminifera. Neues Jb. Geol. Paläontol. Monat. 5, 295-309.

Alegret, L., Molina, E., Thomas, E., 2003. Benthic foraminiferal turnover across the Cretaceous/Paleogene boundary at Agost (southeastern Spain): paleoenvironmental inferences. Mar. Micropaleontol. 48, 251-279.

Alegret, L., Kaminski, M.A., Molina, E., 2004a. Paleoenvironmental recovery after the Cretaceous/Paleogene boundary crisis: evidence from the marine Bidart section (SW France). Palaios 19, 574-586.

Alegret, L., Arenillas, I., Arz, J.A., Molina, E., 2004b. Foraminiferal event-stratigraphy across the Cretaceous/Paleogene boundary. Neues Jb. Geol. Paläontol. Abh. 234, 25-50.

Alegret, L., Arenillas, I., Arz, J.A., Díaz, C., Grajales, M., Meléndez, A., Molina, E., Rojas, R. Soria, A.R., 2005a. Cretaceous/Paleogene boundary deposits at Loma Capiro, central Cuba: evidence for the Chicxulub impact. Geology 33, 721-724.

Alegret, L., Ortiz, S., Arenillas, I., Molina, E., 2005b. Paleoenvironmental turnover across the Paleocene/Eocene Boundary at the Stratotype section in Dababiya (Egypt) based on benthic foraminifera. Terra Nova 17, 526-536.

Alegret, L., Cruz, L.E., Fenero, R., Molina, E., Ortiz, S., Thomas, E., 2008. Effects of the Oligocene climatic events on the foraminiferal record from Fuente Caldera section (Spain, western Tethys). Palaeogeogr. Palaeoclimatol. Palaeoecol. 269, 94-102.

Alegret, L., Ortiz, S., Molina, E., 2009. Extinction and recovery of benthic foraminifera across the Paleocene-Eocene Thermal Maximum at the Alamedilla section (Southern Spain). Palaeogeogr. Palaeoclimatol. Palaeoecol. 279, 186-200.

Alegret, L., Ortiz, S., Arenillas, I., Molina, E., 2010. What happens when the ocean is overheated? The foraminiferal response across the Paleocene-Eocene Thermal Maximum at the Alamedilla section (Spain). Geol. Soc. Am. Bull. 122 (9/10), 1616-1624.

Alegret, L., Thomas, E., Lohmann, K.C., 2012. End-Cretaceous marine mass extinction not caused by productivity collapse. Proc. Natl. Acad. Sci. 109, 728-732.

Alvarez, W., 1997. T. Rex and the Crater of Doom. Princeton University Press.

Alvarez, L.W., Alvarez, W., Asaro, F., Michel, H.V., 1980. Extraterrestrial cause for the Cretaceous-Tertiary extinction. Science 208, 1095-1108.

Alvarez, L.W., Asaro, F., Michel, H.V., Alvarez, L.W., 1982. Iridium anomaly approximately synchronous with terminal Eocene extinctions. Science 216, 886-888.

Apellaniz, E., Baceta, J.I., Bernaola-Bilbao, G., Núñez-Betelu, K., Orue-Etxebarria, X., Pyros, A., Pujalte, V., Robin, E., Rocchia, R., 1997. Analysis of uppermost Cretaceous-lowermost Tertiary hemipelagic successions in the Basque Country (western Pyrenees): evidence for a sudden extinction of more than half of the planktic foraminifer species at the K/T boundary. Bull. Soc. Geol. Fr. 168, 783-793.

Arenillas, I., Molina, E., 1996. Bioestratigrafía y evolución de las asociaciones de foraminíferos planctónicos del tránsito Paleoceno-Eoceno en Alamedilla (Cordilleras Béticas). Rev. Esp. Micropaleontol. 18, 75-96.

Arenillas, I., Molina, E., Schmitz, B., 1999. Planktic foraminiferal and $\partial^{13} \mathrm{C}$ isotopic changes across the Paleocene/Eocene boundary at Possagno (Italy). Int. J. Earth Sci. 88, 352-364.

Arenillas, I., Arz, J.A., Molina, E., Dupuis, C., 2000a. An independent test of planktic foraminiferal turnover across the Cretaceous/Paleogene (K/P) boundary at El Kef, Tunisia: catastrophic mass extinction and possible survivorship. Micropaleontology 46, 31-49.

Arenillas, I., Arz, J.A., Molina, E., Dupuis, C., 2000b. The Cretaceous/Tertiary boundary at Aïn Settara, Tunisia: sudden catastrophic mass extinction in planktic foraminifera. J. Foraminifer. Res. 30, 202-218.

Arenillas, I., Arz, J.A., Molina, E., 2002. Quantifying the evolutionary turnover across the K-T boundary catastrophic planktic foraminiferal extinction event at El Kef, Tunisia. Geol. Fören. Stockh. Förh. 124, 121-126.

Arenillas, I., Arz, J.A., Molina, E., 2004. A new high-resolution planktic foraminiferal zonation and subzonation for the lower Danian. Lethaia 37, 79-95.

Arenillas, I., Arz, J.A., Grajales, M., Murillo, G., Alvarez, W., Camargo, A., Molina, E., Rosales, C., 2006. Chicxulub impact event is Cretaceous/Paleogene boundary in age: new micropaleontological evidence. Earth Planet. Sci. Lett. 249, 241-257.

Arz, J.A., Arenillas, I., Molina, E., Dupuis, C., 1999. Los efectos tafonómico y “Signor-Lipps” sobre la extinción en masa de foraminíferos planctónicos en el límite Cretácico/ Terciario de Elles (Túnez). Rev. Soc. Geol. Esp. 12, 251-267.

Arz, J.A., Arenillas, I., Molina, E., Sepulveda, R., 2000. La estabilidad evolutiva de los foraminíferos planctónicos en el Maastrichtiense superior y su extinción en el límite Cretácico/Terciario de Caravaca, España. Rev. Geol. Chile 27, 27-47.

Arz, J.A., Arenillas, I., Soria, A.R., Alegret, L., Grajales, M., Liesa, C., Meléndez, A., Molina, E., Rosales, M.C., 2001. Micropaleontology and sedimentology of the Cretaceous/Tertiary boundary at La Ceiba (Mexico): impact-generated sediment gravity flows. J. S. Am. Earth Sci. 14 (5), 505-519.
Aubry, M.P., Ouda, K., Dupuis, C., Berggren, W.A., Van Couvering, J.A., Ali, J., Brinkhuis, H., 960 Gingerich, P.R., Heilmann, C., Hooker, J., Kent, D.V., King, C., Knox, R., Laga, P., Molina, 961 E., Schmitz, B., Steurbaut, E., Ward, D.R., 2007. The Global Standard Stratotype-section 962 and Point (GSSP) for the base of the Eocene Series in the Dababiya section (Egypt). 963 Episodes 30 (4), 271-286.

Berggren, W.A., Van Couvering, J.A. (Eds.), 1984. Catastrophes and Earth History: The New 965 Uniformitarianism. Princeton University Press, New Jersey. 966

Bottomley, R.J., York, D., Grieve, R.A.F., 1993. Age of Popigai impact event using the 967 ${ }^{40} \mathrm{Ar}-{ }^{39} \mathrm{Ar}$ method. 24th Lunar and Planetary Science Conference, Houston, Texas. $\quad 968$

Bowen, G.J., Clyde, W.C., Koch, P.L., Ting, S., Alroy, J., Tsubamoto, T., Wang, Y., Wang, Y., 969 2002. Mammalian dispersal at the Paleocene/Eocene boundary. Science 295 (5562), 970 2062-2065.

Brusatte, S.L., Butler, R., Barret, P.M., Carrano, M.T., Evans, D.C., Lloyd, G.T., Mannion, P.D., 972 Norell, M.A., Peppe, D.J., Upchurch, P., Williamson, T.E., 2014. The extinction of the 973 dinosaurs. Biol. Rev. http://dx.doi.org/10.1111/brv.12128.

Canudo, J.I., Molina, E., 1992. Planktic foraminiferal faunal turnover and bio- 975 chronostratigraphy of the Paleocene-Eocene boundary at Zumaya (Northern 976 Spain). Rev. Soc. Geol. Esp. 5, 145-157.

Canudo, J.I., Keller, G., Molina, E., 1991. Cretaceous/Tertiary boundary extinction pattern 978 and faunal turnover at Agost and Caravaca, S.E. Spain. Mar. Micropaleontol. 17, 979 319-341.

Canudo, J.I., Keller, G., Molina, E., Ortiz, N., 1995. Planktic foraminiferal turnover and $\partial^{13} \mathrm{C} 981$ isotopes across the Paleocene-Eocene transition at Caravaca and Zumaya, Spain. 982 Palaeogeogr. Palaeoclimatol. Palaeoecol. 114, 75-100.

Chaloner, W.G., Hallam, A. (Eds.), 1989. Evolution and extinction. Philosophical Transac- 984 tions of the Royal Society of London 325, pp. 241-488

Clymer, A.K., Bice, D.M., Montanari, A., 1996. Shocked quartz from the late Eocene: impact 986 evidence from Massignano, Italy. Geology 24, 483-486.

Coccioni, R., Galeotti, S., 1994. K-T boundary extinction: geologically instantaneous or 988 gradual event? Evidence from deep-sea benthic foraminifera. Geology 22, 779-782. 989

Conzalvo, C., Molina, E., 1996. Bioestratigrafía y cronoestratigrafía del tránsito Eoceno 990 medio-Eoceno superior en la Cordillera Bética. Rev. Esp. Micropaleontol. 27, 25-44. 991

Coxall, H.C., Wilson, P.A., Pälike, H., Lear, C.H., Backman, J., 2005. Rapid stepwise onset of 992 Antarctic glaciation and deeper calcite compensation in the Pacific Ocean. Nature 993 433, 53-57.

Darwin, C., 1859. On the Origin of Species by Means of Natural Selection. John Murray, 995 London.

DeConto, R.M., Pollard, D., 2003. Rapid Cenozoic glaciation of Antarctica triggered by 997 declining atmospheric $\mathrm{CO}_{2}$. Nature 421, 245-249. 998

Dickens, G.R., Castillo, M.M., Walker, J.C.G., 1997. A blast of gas in the latest Paleocene: 999 simulating first-order effects of massive dissociation of the oceanic methane hydrate. 1000 Geology 25, 259-262.

Donovan, S.K. (Ed.), 1989. Mass Extinctions. Processes and Evidence. Belhaven Press, 1002 London.

Dupuis, C., Steurbaut, E., Molina, E., Raucher, R., Tribovillard, N., Arenillas, I., Arz, J.A., 1004 Robaszynski, F., Caron, M., Robin, E., Rochia, R., Lefevre, I., 2001. The Cretaceous- 1005 Paleogene (K/P) boundary in the Ain Settara section (Kalaat Senan, Central Tunisia): 1006 lithological, micropaleontological and geochemical evidence. Bull. Inst. R. Sci. Nat. 1007 Belg. 71, 169-190.

Fischer, A.G, Arthur, M.A. 1977. Secular variations in the pelagic realm. SEPM Spec. Publ. 1009 $25,19-50$.

Gallala, N., Zaghbib-Turki, D., Arenillas, I., Arz, J.A., Molina, E., 2009. Catastrophic mass ex- 1011 tinction and assemblage evolution in planktic foraminifera across the Cretaceous/ 1012 Paleogene (K/Pg) boundary at Bidart (SW France). Mar. Micropaleontol. 72, 196-209. 1013

Ganapathy, R., 1982. Evidence for a major meteorite impact on the earth 34 million years 1014 ago: implications for Eocene extinctions. Science 216, 885-886. 1015

Gingerich, P.D., 2006. Environment and evolution through the Paleocene-Eocene Thermal 1016 Maximum. Trends Ecol. Evol. 21 (5), 246-253.

Glass, B.P., Baker, R.N., Storzer, D., Wagner, G.A., 1973. North American microtektites from 1018 the Caribbean Sea and Gulf of Mexico. Earth Planet. Sci. Lett. 19, 184-192.

Glen, W. (Ed.), 1994. Mass-extinction Debates: How Science Works in a Crisis. Stanford 1020 University Press, Stanford.

Gonzalvo, C., Molina, E., 1992. Bioestratigrafía y cronoestratigrafía del tránsito Eoceno- 1022 Oligoceno en Torre Cardela y Massignano (Italia). Rev. Esp. Paleontol. 7, 109-126. 1023

Gradstein, F.M., Ogg, J.G., Schmitz, M., Ogg, G. (Eds.), 2012. The Geologic Time Scale 20121024 2 vols. Elsevier.

Hallam, A., Vignall, P., 1997. Mass Extinctions and Their Aftermath. Oxford University 102 Press, Oxford.

Hart, M.B. (Ed.), 1996. Biotic Recovery from Mass Extinction Events. Geological Society, 1028 London.

Hartenberger, J.L., 1998. An Asian Grande coupure. Nature 394, 321.

Hazel, J.E., 1989. Chronostratigraphy of Upper Eocene microspherules. Palaios 4, 318-329. 1031

Hickman, C.S., 2003. Evidence for abrupt Eocene-Oligocene molluscan faunal change 1032 in the Pacific Northwest. In: Prothero, D., et al. (Eds.), From Greenhouse to Icehouse. 1033 Columbia University Press, New York, pp. 71-87.

Hut, P., Alvarez, W., Elder, W.P., Hansen, T., Kauffman, E.G., Keller, G., Shoemaker, E.M., 1035 Weissman, P.R., 1987. Comet showers as a cause of mass extinctions. Nature 329, 1036 $118-126$.

Kaiho, K., 1994. Planktonic and benthic foraminiferal extinction events during the last 1038 100 Myr. Palaeogeogr. Palaeoclimatol. Palaeoecol. 11, 45-71.

Kaiho, K., Lamolda, M., 1999. Catastrophic extinction of planktonic foraminifera at the 1040 Cretaceous-Tertiary boundary evidenced by stable isotopes and foraminiferal abun- 1041 dance at Caravaca, Spain. Geology 27, 355-358. (2012. Radiolarian magnetobiochronology and faunal turnover 1043 across the middle/late Eocene boundary at Ocean Drilling Program Site 1052 in the 1044 western North Atlantic Ocean. Mar. Micropaleontol. 88-89, 41-53. 
Kauffman, E.G., 1988. The dynamics of marine stepwise mass extinction. Revista Española de Paleontología $\mathrm{N}^{\circ}$ Extra, pp. 57-71.

1048 Kauffman, E.G., Erwin, D.H., 1995. Surviving mass extinctions. Geotimes 14, 14-17.

1049 Kauffman, E.G., Harries, P.J., 1996. Las consecuencias de la extinción en masa: prediciones para la supervivencia y regeneración en ecosistemas antiguos y modernos. In: Agustí, J. (Ed.), La lógica de las extincionesMetatemas 42. Tusquets Editores, Barcelona, pp. 17-64.

Kauffman, E.G., Walliser, O.H. (Eds.), 1990. Extinction events in Earth historyLecture Notes in Earth Sciences. Springer-Verlag, Berlin.

Keller, G., 1988. Extinction, survivorship and evolution of planktic foraminifers across the Cretaceous/Tertiary boundary at El Kef, Tunisia. Mar. Micropaleontol. 13, 239-263.

Keller, G., 2012. The Cretaceous-Tertiary mass extinction, Chicxulub impact, and Deccan volcanism. In: Talent, J.A. (Ed.), Earth and Life. Springer, pp. 759-793.

Keller, G., D'Hondt, S., Orth, C.J., Gilmore, J.S., Oliver, P.Q., Shoemaker, E.M., Molina, E., 1987 Late Eocene impact microspherules: stratigraphy, age and geochemistry. Meteoritics $22,25-60$.

Keller, G., Li, L., MacLeod, N., 1995. The Cretaceous/Tertiary boundary stratotype section at El Kef, Tunisia: how catastrophic was the mass extinction? Palaeogeogr. Palaeoclimato Palaeoecol. 119, 221-254.

Kennett, J.P., Schackleton, N.J., 1976. Oxygen isotopic evidence for the development of the psychrosphere 38 Myr ago. Nature 260, 513-515.

Kennett, J.P., Stott, L.D., 1991. Abrupt deep-sea warming, palaeoceanographic changes and benthic extinctions at the end of the Palaeocene. Nature 353, 225-229.

Kent, D.V., Cramer, B.S., Lanci, L., Wang, D., Wright, J.D., Van der Voo, R., 2003. A case for a comet impact trigger for the Paleocene/Eocene Thermal Maximum and carbon isotope excursion. Earth Planet. Sci. Lett. 211, 13-26.

Koeberl, C., Poag, C.W., Reimold, W.U., Brandt, D., 1996. Impact origin of the Chesapeake Bay structure and the source of the North American tectites. Science 271, 1263-1266.

amolda, M.A., Orue-Etxebarria, X., Proto-Decima, F., 1983. The Cretaceous-Tertiary boundary in Sopelana (Biscay, Basque Country). Zitteliana 10, 663-670.

Leakey, R., Lewin, R., 1995. The Sixth Extinction. Patterns of Life and the Future of Humankind. Doubleday, New York

Livermore, R., Nankivell, A., Eagles, G., Morris, P., 2005. Paleogene opening of Drake Passage. Earth Planet. Sci. Lett. 236, 459-470.

Lu, G., Keller, G., Adatte, T., Ortiz, N., Molina, E., 1996. Long-term (105) or short-term (103) $\partial^{13} \mathrm{C}$ excursion near the Paleocene-Eocene transition: evidence from the Tethys. Terra Nova 8, 347-355.

Luterbacher, H.P., Premoli Silva, I., 1964. Biostratigrafia del limite Cretaceo-Terziario nell'Appennino Centrale. Riv. Ital. Paleontol. Stratigr. 70, 67-128.

MacLeod, K.G., Whitney, D.L., Huber, B.T., Koeberl, C., 2007. Impact and extinction in remarkably complete Cretaceous-Tertiary boundary sections from Demerara Rise tropical western North Atlantic. Geol. Soc. Am. Bull. 119 (1-2), 101-115.

Martínez Gallego, J., Molina, E., 1975. Estudio del tránsito Eoceno-Oligoceno con foraminíferos planctónicos al Sur de Torre Cardela (Provincia de Granada, Zona Subbética). Cuad. Geol. 6, 177-195

McGowran, B., 2012. Cenozoic environmental shifts and foraminiferal evolution. In: Talent, J.A. (Ed.), Earth and Life. Springer, pp. 937-965.

McInerney, F.A., Wing, S.L., 2011. The Paleocene-Eocene Thermal Maximum: a perturbation of carbon cycle, climate, and biosphere with implications for the future. Annu. Rev. Earth Planet. Sci. 39, 489-516.

Molina, E., 1986. Description and biostratigraphy of the main reference section of the Eocene/Oligocene boundary in Spain: Fuente Caldera section. In: Pomerol, Ch. Premoli Silva, I. (Eds.), Terminal Eocene Events. Elsevier, Amsterdam, pp. 53-63.

Molina, E. (Ed.), 1994. Extinction and the Fossil Record: Cuadernos Interdisciplinares 5.

Molina, E., 1995. Modelos y causas de extinción masiva. Interciencia 20, 83-89.

Molina, E. (Ed.), 2004. Micropaleontología, second ed. Colección Textos Docentes. Prensas Universitarias de Zaragoza.

Molina, E., 2006. Evidencias y causas de los principales eventos del Paleógeno basadas en los patrones de extinción y supervivencia de los foraminíferos. Rev. Esp. Paleontol. 21 (2), 159-173.

Molina, E., 2007. Causas de los principales eventos de extinción en los últimos 66 millones de años. Rev. Real Acad. Cienc. Zaragoza 62, 37-64.

Molina, E., Keller, G., Madile, M., 1988. Late Eocene to Oligocene events: Molino de Cobo, Betic Cordillera, Spain. Rev, Esp. Micropaleontol. 20, 491-514.

Molina, E., Gonzalvo, C., Keller, G., 1993. The Eocene-Oligocene planktic foraminifera transition: extinctions, impacts and hiatuses. Geol. Mag. 130, 483-499.

Molina, E., Canudo, J.I., Martínez, F., Ortiz, N., 1994. Integrated stratigraphy across the Paleocene/Eocene boundary at Caravaca, Southern Spain. Eclogae Geol. Helv. 87, 47-61.

Molina, E., Arenillas, I., Arz, J.A., 1996. The Cretaceous/Tertiary boundary mass extinction in planktic foraminifera at Agost, Spain. Rev. Micropaleontol. 39, 225-243.

Molina, E., Arenillas, I., Arz, J.A., 1998. Mass extinction in planktic foraminifera at the Cretaceous/Tertiary boundary in subtropical and temperate latitudes. Bull. Soc. Geol. Fr. 169, 351-363.

Molina, E., Arenillas, I., Pardo, A., 1999. High resolution planktic foraminiferal biostratigraphy and correlation across the Paleocene/Eocene boundary in the Tethys. Bull. Soc Geol. Fr. 170, 521-530.

Molina, E., Alegret, L., Arenillas, I., Arz, J.A., 2002. Taphonomy in analysis of the pattern of extinction at the Cretaceous/Tertiary boundary. In: DeRenzi, M. (Ed.), Current Topics on Taphonomy and Fossilization, pp. 89-95 (Valencia).

Molina, E., Alegret, L., Arenillas, I., Arz, J.A., 2005. The Cretaceous/Paleogene boundary at the Agost section revisited: paleoenvironmental reconstruction and mass extinction pattern. J. Iber. Geol. 31, 135-148.

Molina, E., Alegret, L., Arenillas, I., Arz, J.A., Gallala, N., Hardenbol, J., Von Salis, K. Steurbaut, E., Vandenbeghe, N., Zaghbib-Turki, D., 2006a. The global boundary stratotype section and point for the base of the Danian Stage (Paleocene, Paleogene,
"Tertiary" Cenozoic) at El Kef, Tunisia: original definition and revision. Episodes 291132 (4), 263-278.

1133

Molina, E., Gonzalvo, C., Ortiz, S., Cruz, L.E., 2006b. Foraminiferal turnover across the Eocene- 113 Oligocene transition at Fuente Caldera, southern Spain: no cause-effect relationship 1135 between meteorite impacts and extinctions. Mar. Micropaleontol. 58, 270-286. 1136

Molina, E., Alegret, L., Arenillas, I., Arz, J.A., Gallala, N., Grajales-Nishimura, M., Murillo- 1137 Muñetón, G., Zaghbig-Turki, D., 2009. The global boundary stratotype section and 1138 point for the base of the Danian Stage (Paleocene, Paleogene, "Tertiary", Cenozoic): 1139 auxiliary sections and correlation. Episodes 32 (2), 84-95.

1140

Montanari, A., Asaro, F., Michel, H.V., Kennett, J.P., 1993. Iridium anomalies of late Eocene 114 age at Massignano (Italy), and ODP Site 689B (Maud Rise, Antarctic). Palaios 8, 1142 $430-437$.

1143

oreau, C., Dory, D., 2005. Alcide d'Orbigny entre Europe et Amérique. Presses Universitaires 114 de Rennes.

Ohno, S., Kadono, T., Kurosawa, K, Hamura, T., Sakaiya, T., Shigemori, K, Hironaka, Y, 1146 Sano, T. Watari, T, Otani, K, Matsui, T, Sugita, S, 2014. Production of sulphate-rich 1147 vapour during the Chicxulub impact and implications for ocean acidification. Nat. 1148 Geosci. 7, 279-282.

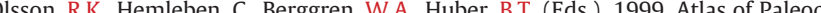
planktonic foraminifera. Smithsonian Contributions to Paleobiology 85. 1151

Orth, C., Gilmore, J., Knight, J., Pillmore, C., Tschudy, R., Fassett, J., 1981. An iridium abun- 1152 dance anomaly at the palynological Cretaceous-Tertiary boundary in northern New 1153 México. Science 214, 1341-1342.

Orue-Etxebarria, X., 1997. El Kef blind test IV results. Mar. Micropaleontol. 29, 85-88. 1155

Orue-Etxebarria, X., Apellaniz, E., Baceta, J.L., Cocción, R., Di Leo, R., Dinarés-Turell, J., 1156 Galeotti, S., Monechi, S., Núñez-Betelu, K., Parés, J.M., Payros, A., Pujalte, V., Samsó, 1157 J.M., Serra-Kiel, J., Schmitz, B., Tosquella, J., 1996. Physical and biostratigraphic analy- 1158 sis of two prospective Paleocene-Eocene boundary stratotypes in the intermediate- 1159 deep water Basque Basin, western Pyrenees: the Trabaka Pass and Ermua sections. 1160 Neues Jb. Geol. Paläontol. Abh. 201, 197-242.

Orue-Etxebarria, X., Pujalte, V., Bernaola, G., Apellaniz, E., Baceta, J.I., Payros, A., Núñez- 1162 Betelu, K., Serra-Kiel, J., Tosquella, J., 2001. Did the late Paleocene Thermal Maximum 1163 affect the evolution of larger foraminifers? Evidence from calcareous plankton of the 1164 Campo section (Pyrenees, Spain). Mar. Micropaleontol. 41, 45-71.

1165

Orue-Etxebarria, X., Bernaola, G., Baceta, J.L., Angori, E., Caballero, F., Monechi, S., Pujalte, V., 1166 Dinarès-Turell, J., Apellaniz, E., Payros, A., 2004. New constraints on the evolution of 1167 planktic foraminifers and calcareous nannofossils across the Paleocene-Eocene bound- 1168 ary interval: the Zumaia section revisited. Neues Jb. Geol. Paläontol. Abh. 234, 223-259. 1169

Owen, R.M., Rea, D.K., 1992. Sea floor hydrothermal activity links climate to tectonics: the 1170 Eocene $\mathrm{CO}_{2}$ greenhouse. Science 227, 166-169.

Palmer, T., 2003. Perilous Planet Earth. Cambridge University Press, Cambridge.

1171

Pearson, P.N., Olsson, R.K., Huber, B.T., Hemleben, C., Berggren, W.A. (Eds.), 2006. Atlas of 1173 Eocene planktonic foraminifera. Cushman Foundation for Foraminiferal Research, 1174 Special Publication 41.

Pearson, P.N., Foster, G.L., Wade, B.S., 2009. Atmospheric carbon dioxide through the 1176 Eocene-Oligocene climate transition. Nature 461, 1110-1114.

Pearson, P.N., McMillan, I.K., Wade, B.S., Dunkley Jones, T., Coxall, H.K., Bown, P.R., Lear, 1178 H.L., 2013. Extinction and environmental change across the Eocene-Oligocene 1179 boundary in Tanzania. Geology 36, 179-182.

Peryt, D., Alegret, L, Molina, E., 2002. The Cretaceous/Paleogene (K/P) boundary at Aïn 1181 Settara, Tunisia: restructuring of benthic foraminiferal assemblages. Terra Nova 14,1182 101-107.

Pierrard, O., Robin, E., Rocchia, R., Montanari, A, 1998. Extraterrestrial Ni-rich spinel in 1184 upper Eocene sediments from Massignano, Italy. Geology 26, 307-310. 1185

Poag, C.W., Mankinen, E., Norris, R.D., 2003. Late Eocene impacts: geologic record, corre- 1186 lation and paleoenvironmental consequences. In: Prothero, D., et al. (Eds.), From 1187 Greenhouse to Icehouse. Columbia University Press, New York, pp. 495-510. 1188

Premoli Silva, I., Jenkins, D.G., 1993. Decision on the Eocene-Oligocene boundary 1189 stratotype. Episodes 16 (3), 379-382.

The Eocene-Oligocene boundary in the Marche-Umbria basin Italy. In: Premoli Silva, I, 1191 Coccioni, R., Montanari, A. (Eds.), Proceedings of the Eocene-Oligocene Boundary 1192 Meeting, Ancona, 1987. Annibali/IUGS.

Prothero, D.R., 1994. The Eocene-Oligocene Transition: Paradise Lost. Columbia University 1194 Press, New York. Acad. Sci. U. S. A. 81, 801-805.

Robin, E Molina, E 2006. Chronostratigraphy, composition and source of Ni-rich spinel in the late Eocene Fuente Caldera section (Spain): one impact or more? Meteorit. 1200 Planet. Sci. 41 (8), 1231-1248.

Rudwick, MJ.S, 2008. Georges Cuvier, Fossil Bones, and Geological Catastrophes. Univer- 1202 sity of Chicago Press.

Schindewolf, O., 1963. Neokatastrophismus. Z. Dtsch. Geol. Ges. 114, 430-445. 1204

Schmitz, B., Asaro, F., Molina, E., Monechi, S., Von Salis, K., Speijer, R.P., 1997. High- 1205 resolution iridium, $\partial^{13} \mathrm{C}, \partial^{18} \mathrm{O}$, foraminifera and nannofossil profiles across the latest 1206 Paleocene benthic extinction event at Zumaya, Spain. Palaeogeogr. Palaeoclimatol. 1207 Palaeoecol. 133, 49-68.

Schmitz, B., Peucher-Ehrenbrink, B., Heilmann-Clausen, C., Aberg, G., Lee, C.-T.A., 2004. Ba- 1209 saltic explosive volcanism, but no comet impact, at the Paleocene-Eocene boundary: 1210 high-resolution chemical and isotopic records from Egypt, Spain and Denmark. Earth 1211 Planet. Sci. Lett. 225, 1-17. G.L., Claeys, P., Cockell, C.S., Collins, G.S., Deutsch, A., Goldin, T.J., Goto, K., Grajales- 121 Nishimura, J.M., Grieve, R.A.F., Gulick, S.P.S., Johnson, K.R., Kiessling, W., Koeberl, C., 1215 Kring, D.A., MacLeod, K.G., Matsui, T., Melosh, J., Montanari, A., Morgan, J.V., Neal, 1216 C.R., Nichols, D.J., Norris, R.D., Pierazzo, E., Ravizza, G., Rebolledo-Vieyra, M., Reimold, 1217 
W.U., Robin, E., Salge, T., Speijer, R.P., Sweet, A.R., Urrutia-Fucugauchi, J., Vajda, V. Whalen, M.T., Willumsen, P.S., 2010. The Chicxulub asteroid impact and mass extinction at the Cretaceous-Paleogene boundary. Science 327, 1214-1218.

Shackleton, N.J., Kennett, J.P., 1975. Paleotemperature history of the Cenozoic and the initiation of Antarctic glaciation: oxygen and carbon isotope analyses in DSDP Sites 277. 279 and 281. Init. Rep. Deep Sea Drilling Proj. 29, 743-755.

Signor, P.W., Lipps, J.H., 1982. Sampling bias, gradual extinction patterns and catastrophes in the fossil record. Geol. Soc. Am. Spec. Pap. 190, 291-296.

Sloan, L.C., Walker, J.C.G., Moore Jr., T.C., Rea, D.K., Zachos, J.C., 1992. Possible methaneinduced polar warming in the early Eocene. Nature 357, 320-322.

Smit, J., 1982. Extinction and evolution of planktonic foraminifera after a major impact at the Cretaceous/Tertiary boundary. Geol. Soc. Am. Spec. Pap. 190, 329-352.

Smit, J., 1990. Meteorite impact, extinctions and the Cretaceous-Tertiary boundary. Geol. Mijnb. 69, 187-204.

Smit, J., Hertogen, J., 1980. An extraterrestrial event at the Cretaceous-Tertiary boundary. Nature 285, 198-200.

Speijer, R., Schmitz, B., Luger, P., 2000. Stratigraphy of late Palaeocene events in the Middle East: implications for low- to middle-latitude successions and correlations. J. Geol. Soc. Lond. 157, 37-47.

Speijer, R., Scheibner, C., Stassen, P., Morsi, A.M., 2012. Response of marine ecosystems to deep-time global warming: a synthesis of biotic patterns across the PaleoceneEocene Thermal Maximum (PETM). Aust. J. Earth Sci. 105 (1), 6-16.

Svensen, H., Planke, S., Malthe-Sorenssen, A., Jamtveit, B., Myklebust, R., Eidem, T.R., Rey, S.S., 2004. Release of methane from a volcanic basin as a mechanism for initial Eocene global warming. Nature 429, 542-545.

Taylor, P.D. (Ed.), 2004. Extinctions in the History of Life. Cambridge University Press, Cambridge.

Thomas, E., 2003. Extinction and food at the sea floor: a high-resolution benthic foraminiferal record across the Initial Eocene Thermal Maximum, Southern Ocean Site 690. In: Wing, S., et al. (Eds.), Causes and Consequences of Globally Warm Climates of the PaleogeneGeol. Soc. Am. Spec. Pap. 369, 319-332.

Thomas, E., 2007. Cenozoic mass extinctions in the deep sea: what perturbs the largest habitat on Earth? Geol. Soc. Am. Spec. Pap. 424, 1-23.

Thomas, E., Shackleton, N.J., 1996. The Paleocene-Eocene benthic foraminiferal extinction and stable isotope anomalies. Geol. Soc. Am. Spec. Publ. 1001, 401-441.
Thomas, E., Zachos, J.C., 2000. Was the late Paleocene thermal maximum a unique event? 1253 Geol. Fören. Stockh. Förh. 122, 169-170.

Tripati, A., Backman, J., Elderfield, H., Ferretti, P., 2005. Eocene bipolar glaciation associated 1255 with global carbon cycle changes. Nature 436, 341-346.

Twitchett, R.J., 2006. The palaeoclimatology, palaeoecology and palaeoenvironmental 1257 analysis of mass extinction events. Palaeogeogr. Palaeoclimatol. Palaeoecol. 232, 1258 190-213.

Vandenberghe, N., Hilgen, F.J., Speijer, R.P., 2012. The Paleogene Period. In: Gradstein, F.M., 1260 et al. (Eds.), The Geologic Time Scale 2012. Elsevier, pp. 855-921.

1261

Vellekoop, J., Sluijs, A., Smit, J., Schouten, S., Weijers, J.W., Sinninghe Damsté, J.S., 1262 Brinkhuis, H., 2014. Rapid short-term cooling following the Chicxulub impact at the 1263 Cretaceous-Paleogene boundary. PNAS 111 (21), 7537-7541. 1264

Venkatesan, T.R., Pande, K., Gopalan, K., 1993. Did Deccan volcanism pre-date the 1265 Cretaceous/Tertiary transition? Earth Planet. Sci. Lett. 119, 181-189. 1266

Wade, B.S., 2004. Planktonic foraminiferal biostratigraphy and mechanisms in the 1267 extinction of Morozovella in the late middle Eocene. Mar. Micropaleontol. 51, 1268 23-38.

Wade, B.S., Pearson, P.N., 2008. Planktonic foraminiferal turnover, diversity fluctuations 1270 and geochemical signals across the Eocene/Oligocene boundary in Tanzania. Mar. 1271 Micropaleontol. 68, 244-255. 1272

Wade, B.S., Pearson, P.N., Berggren, W.A., Pälike, H., 2011. Review and revision of Cenozoic 1273 tropical planktonic foraminiferal biostratigraphy and calibration of the geomagnetic 1274 polarity and astronomical time scale. Earth Sci. Rev. 104, 111-142. 1275

Winguth, A.M.E., Thomas, E., Winguth, C., 2012. Global decline in ocean ventilation, 1276 oxygenation, and productivity during the Paleocene-Eocene Thermal Maximum: 1277 implications for the benthic extinction. Geology 40 (3), 263-266. 1278

Wonhof, H.B., Smit, J., Brinkhuis, H., Montanari, A., Nederbragt, A.J., 2000. Global cooling 1279 accelerated by early late Eocene impacts. Geology 28, 687-690. 1280

Zachos, J.C., Pagani, M., Sloan, L., Thomas, E., Billups, K., 2001. Trends, rhythms, and aber- 1281 rations in global climate 65 Ma to Present. Science 292, 686-693. 1282

Zachos, J.C., Dickens, G.R., Zeebe, R.E., 2008. An early Cenozoic perspective on green house 1283 warming and carbon-cycle dynamics. Nature 451, 279-283.

Zili, L., Zaghbib-Turki, D., Alegret, L., Arenillas, I., Molina, E., 2009. Foraminiferal turnover 1285 across the Paleocene/Eocene boundary at the Zumaya section, Spain: record of a 1286 bathyal gradual mass extinction. Rev. Mex. Cienc. Geol. 26 (3), 729-744. 